\title{
Preliminary Analysis of the Environmental Effects on RNA Degradation: Modeling a Realistic Crime Scene
}

Beatriz A. Vianna

West Virginia University

Follow this and additional works at: https://researchrepository.wvu.edu/etd

\section{Recommended Citation}

Vianna, Beatriz A., "Preliminary Analysis of the Environmental Effects on RNA Degradation: Modeling a Realistic Crime Scene" (2010). Graduate Theses, Dissertations, and Problem Reports. 4666.

https://researchrepository.wvu.edu/etd/4666

This Thesis is protected by copyright and/or related rights. It has been brought to you by the The Research Repository @ WVU with permission from the rights-holder(s). You are free to use this Thesis in any way that is permitted by the copyright and related rights legislation that applies to your use. For other uses you must obtain permission from the rights-holder(s) directly, unless additional rights are indicated by a Creative Commons license in the record and/ or on the work itself. This Thesis has been accepted for inclusion in WVU Graduate Theses, Dissertations, and Problem Reports collection by an authorized administrator of The Research Repository @ WVU. For more information, please contact researchrepository@mail.wvu.edu. 


\title{
Preliminary Analysis of the Environmental Effects on RNA Degradation: Modeling a Realistic Crime Scene
}

\author{
Beatriz A. Vianna
}

\author{
Thesis \\ Submitted to the Eberly College of Arts and Sciences \\ at West Virginia University \\ In Partial Fulfillment of the Requirements \\ For the Degree of \\ Master of Science \\ In \\ Biology
}

Committee Members:

Dr. Clifton Bishop, chair

Dr. Ashok Bidwai

Dr. David Ray

Department of Biology

Morgantown, $W V$

2010

Key Words: Forensics Sciences, RNA degradation, Bloodstains, Real-time RT PCR, Accumulated Degree Days 


\title{
ABSTRACT
}

\section{Preliminary Analysis of the Environmental Effects on RNA Degradation: Modeling a Realistic Crime Scene}

\section{Beatriz Alves Vianna}

\begin{abstract}
In forensic science, polymerase chain reaction (PCR) became an indispensable tool given the limited amount of biological samples usually encountered at crime scenes. DNA analysis is used to identify the source of biological samples typically obtained from a single hair, or droplet of blood. Determining the source of the biological evidence can provide a spatial link, thereby including or excluding a suspect at a crime scene or other locations related to a crime investigation. In spite of the great efficiency in human identification, DNA analysis cannot provide any information regarding time of deposition of the sample. The ability to establish a temporal connection reveals key information for crime scene reconstruction and evidence interpretation; this is especially true when determining if the DNA sample found at the crime scene was left at the moment of the crime or originated from an unrelated event. Estimating the age of the biological sample would be particularly important in cases where the victim and suspect are known to have a personal relationship. The development of quantitative reversetranscription real-time polymerase chain reaction, has stimulated scientist to explore the potential use of RNA as a forensic tool. Multiple studies have reported the use of RNA analysis on body fluid identification, age determination of injuries and wounds and for post-mortem interval (PMI). Previously, our laboratory has shown that the estimation of age of a biological sample can be determined by measuring the degradation rates of two different RNA segments using real-time RT PCR method. In addition, it has also been demonstrated that, under controlled conditions, RNA decay proceeds in a predictable fashion. However, it is unrealistic to expect that in real crime scenes the biological sample will be exposed to an invariable environment. We investigated the environmental effects on $\beta$-actin and 18S RNAs decay, more specifically; the effects of fluctuating temperatures and humidity by exposing bloodstain samples in two different rooms at WVU's Crime House One during a 90 day period. Daily temperature and relative humidity were recorded in each room. We also investigated the potential use of outdoor temperature to predict indoor temperature. In addition, we investigated the incorporation of accumulated degree days (ADD) into RNA degradation analysis in order to take into account the temperature changes in a non-controlled environment. We believe this will allow for a more accurate and reliable method for estimating time of deposition of blood samples. Our results indicate that the environmental conditions had an effect on the degradation rate of both $\beta$-actin and $18 \mathrm{~S}$ RNAs. The basement environment presented high but generally constant temperature and RNA decay occurred in a linear, predictable fashion. However, the accuracy of our estimation method was extremely decreased in a highly variable environment (attic). This suggests that our assay would only be accurate if there is no extreme fluctuation in temperature. Finally, our results show the importance of knowing the environmental conditions for an accurate estimation of time of deposition and how the data interpretation could be
\end{abstract}


affected, if this information is unknown. After the 90 day exposure period, the basement had an ADD value of 1,496.047 while the attic had an ADD of 508.967 and the airport ADD was 143.111. Thus, using the ADD from one of these environments to estimate time of deposition on the other could lead to estimating the age of the sample as "older" or "younger" then it's true value. 


\section{ACKNOWLEDGEMENTS}

First, I would like to thank my advisor, Dr. Clifton Bishop, for accepting me as part of his lab. I appreciate all guidance and support you gave me through the easy and hard moments of my research. I learned a lot from you and I am really thankful for the opportunity you gave me. You certainly had a major impact on my professional development. Second, I would like to thank my committee members, Dr. Ashok Bidwai and Dr. David Ray, for their time and assistance. I am truly grateful. I would also like to thank my former advisor Dr. Iuri Drummond Louro, for believing and encouraging me to move to the USA and study at West Virginia University. You helped mold me professionally and I will be forever thankful for that. You inspired me to be a better person and a better professional.

Special thanks to the members of my lab, Stephanie Young, Tiffany Smith, Swati Banerjee and former member Regina Trott for their support and friendship. I learned a lot from you and I am very grateful for all that.

I would like to thank my friends: Alyssa Hanna, Mohna Bandyopadhya, Heather Baile, Lois Wright, Wendy Sites and Pat Lutsie for the emotional support, and for always being there for me. You made my life here at West Virginia University better and a little bit easier to be so far away from my family. I would have not made through these few years if I had not had you cheering me up.

In addition, I would like to thank all faculty, graduate students and staff from the Department of Biology for their friendship and support, and a special thanks to Dr. Withers for all the times I stopped by your office to talk. You were always so supportive and you taught me a lot. Also, I would like to thank Mike Bell and the Forensic \& Investigative Sciences Department 
for giving me access to Crime House One. This research would have not being possible without this and I am very grateful for that.

Most importantly, I would like to thank my mom, my dad, my brothers, for always believing in me and for their unconditional love and support through all my life. To my uncles Wallace and Vel, and my aunts Vania and Kara for taking care of me during my first months in the US. I will always be thankful for all the love and support you gave me. I love each and every one of you with all my heart. Thanks to Zach, for being part of my life, for your love and for always being there for me when I needed someone to give me strength to keep going, to believe in myself and to never give up. You made me better person and you complete me. 


\section{TABLE OF CONTENTS}

Title Page

i

Abstract

ii - iii

Acknowledgements

iv - v

Table of Contents

vi

List of Tables

vii

List of Figures

viii

Introduction

$1-3$

RNA as a Forensic Tool

3-7

Accumulated Degree Day (ADD)

$7-8$

Material and Methods

Sample Preparation, Storage and Collection

Temperature and Humidity Monitoring

$10-11$

Multiplex Re-optimization

$11-12$

RNA Isolation

$12-13$

Genomic Screening

cDNA Synthesis

Real - Time Polymerase Chain Reaction

$14-15$

Statistical Analysis

Accumulated Degree Days (ADD) Calculation

15 - 16

2 - $\Delta$ CT Statistical Method

$16-17$

Results

Multiples Re-optimization

Genomic Screening

$19-20$

Temperature and Relative Humidity

$20-21$

RNA Decay vs. ADD

$21-22$

Discussion

$37-41$

References

$42-46$

Appendix I

Daily Temmperature Readings - December, 2009 - March, 2010

47 - 49

Daily Relative Humidity Reading-December, 2009 - March, 2010

50 - 52 


\section{LIST OF TABLES}

Table1. Primers and Probes sequences and estimated amplicon size

Table 2. Multiplex real-time PCR Master Mix Reactions

Table 3: Accumulated Degree Days. 


\section{LIST OF FIGURES}

Figure 1. Amplification Plot of Real-time PCR

Figure 2. Amplification Efficiency of $\beta$-actin mRNA Multiplex.

Figure 3. Amplification Efficiency of 18s rRNA Multiplex.

Figure 4. $\beta$-actin mRNA Degradation Over-time - Basement

Figure 5. $\beta$-actin mRNA Degradation Over-time - Attic

Figure 6. $\beta$-actin mRNA Degradation Over-time

Figure 7.18S rRNA Degradation Over-time - Basement

Figure 8.18S rRNA Degradation Over-time - Attic

Figure 9. 18S rRNA Degradation Over-time

Figure 10. Crime House One Temperature Data.

Figure 11. Crime House One Relative Humidity Data.

Figure 12. Comparative Analysis of Temperature

Figure 13 Average Relative Humidity (\% RH) Comparisons 


\section{INTRODUCTION}

Since its development in 1983, by Karry Mullis, the polymerase chain reaction (PCR) became an essential tool in medical and biological research fields $(1,2)$. This rapid and relatively inexpensive technique revolutionized the field of molecular biology by allowing the amplification of a few nucleic acid molecules (DNA or RNA) generating a much larger amount of copies that can be used in a variety of studies such as detection and diagnosis of infectious or hereditary diseases and recombinant DNA technology $(1,3,4)$. Especially in Forensic Sciences, the PCR method is a vital tool because of a generally limited amount of biological samples that are left at a crime scene. Thus, more often than not, DNA analysis is used to identify the source of biological samples typically obtained from a single hair, or droplet of blood. Determining the source of the biological evidence can provide a spatial link, thereby including or excluding a suspect at a crime scene or other locations related to a crime investigation $(1,3,5,6)$.

Spatial linkage is possible by analyzing and comparing short tandem repeat (STR) sequences found in the human genome. STR loci consist of sequences of 2-7 base pairs tandemly repeated in variable number of copies that differ from individual to individual (2). DNA typing utilizes a combination of different STR loci to create a DNA profile that allows differentiation among individuals and has been widely used in paternity and forensic cases $(2,7)$. In crime scene investigations, DNA profiling allows for the linkage of a suspect or victim to a crime scene $(3,7$ 11). Therefore, it is possible to establish a linkage or association of victim to suspect, suspect to scene, or victim to scene. In spite of the great efficiency in human identification, there are some important questions that cannot be answered by DNA analysis such as: what is the type of biological sample found; when or how it was deposited; and if it can be associated with the crime 
$(6,12)$. For instance, DNA profiling is not able to detect the biological material's time of deposition or provide tissue identification $(4,6,11,12)$. Therefore, the ability to establish a temporal connection reveals key information for crime scene reconstruction and evidence interpretation; this is especially true when determining if the DNA sample found at the crime scene was left at the moment of the crime or originated from an unrelated event. Additionally, the accurate identification of tissues or body fluid samples is needed $(13,14)$. Furthermore, estimating the age of the biological sample would be particularly important in cases where victim and suspect are known to have a personal relationship $(10,11)$. In this case, it would not be uncommon to find DNA evidence from victim and/or suspect at the crime scene or other location of interest. Accordingly, the sample could have been deposited at the crime scene previous to the crime being committed. Thus, the location of the biological sample would not be an incriminating factor, in the absence of other evidence. Without the ability to determine the age of deposition, crime scene reconstruction and analysis could be misinterpreted (4, 13-15).

Given its large attention by the media, the Orenthal James Simpson murder case provides a great example that demonstrates the importance of the development of a reliable method to estimate time of deposition and how the lack of this information could mislead an investigation thereby incriminating an innocent or absolving a guilty suspect (10). In 1995, O. J. Simpson was charged with the murder of his ex-wife, Nicole Brown Simpson, and her friend, Ronald Goldman. Mrs. Simpson's blood was found in the vehicle owned by O.J. Simpson. While the prosecution argued that Simpson was guilty and had transferred his ex-wife's blood to the vehicle when leaving the crime scene, the defense's argument was that the blood evidence encountered in O. J. Simpson's car came from an earlier incident. However, the lack of a method to estimate the age of Mrs. Simpson's blood sample, which would link or exclude the DNA 
evidence to/from the moment of the crime, led to an inability to support or reject both the prosecution's and the defense's arguments $(10,11,16)$.

\subsection{RNA as a Forensic Tool}

DNA-based methods, or more specifically, the use of STR loci analysis for DNA profiling have revolutionized the field of forensic science by providing crucial insight into the reconstruction of crime scenes. As a consequence of its usefulness as an identification tool, it is

clear that forensic science has been heavily focused on DNA research for the past decade (12-14, 17). Furthermore, the assumption that RNA is a very unstable molecule, highly vulnerable to degradation by the action of ubiquitous ribonucleases (RNases), has discouraged scientist from investigating the potential use of RNA technologies as a forensic tool (18). The apparent instability of RNA is based on analysis of in vivo mRNA activity; however, the behavior of RNA molecules in dried stains is still unclear $(12,18)$.

Recent advances in forensic research have revealed RNA as a potential forensic tool for evidence analysis and interpretation. Multiple studies have reported the identification of messenger RNA (mRNA) in postmortem brain, kidney, liver and heart up to 12 hours after death, thus, suggesting prospective utility in forensic pathology for determining the age of external and/or internal wounds $(4,6,11,12,19)$. Moreover, in 2008, Zubakov et al. published work illustrating the employment of stable, tissue-specific RNA markers for identification of blood and saliva stains, and subsequently, in 2009, reported tissue-specific expression of different microRNA (miRNA) molecules, an observation that could be utilized in forensic identification of body fluids such as saliva, vaginal secretion, menstrual blood, venous blood, and semen (12, 
14, 20). Furthermore, previous studies in our lab have demonstrated the use of protamine mRNA as a potential candidate for semen stain identification (21). Thus, RNA analysis has undoubtedly earned its place in processing and interpretation of crime scene evidence as well as in providing crucial answers that, oftentimes, DNA profiling by itself cannot obtain. In addition, an RNAbased approach presents several advantages over earlier techniques used for evidence analysis such as immunological, serological or biochemical assays (11). Compatibility with DNA isolation techniques allows for simultaneous isolation of RNA and DNA from the same sample, thus reducing sample consumption for the DNA profile, body fluid identity and time of deposition $(5,10)$. Moreover, the presence of polymorphisms in RNA can be used to design species-specific primers and probes for a highly discriminatory assay. Finally, some RNA species are constitutively expressed in order to maintain basal cellular functions ("housekeeping" functions). In other words, "housekeeping" RNAs are expressed in all tissues, allowing for the application of RNA-based approaches to analyze any possible biological sample $(5,17)$.

Besides stain identification, several publications have shown that RNA analysis may be a valuable method of determining the age of biological stains such as blood and saliva, which in fact represent the most common sources of biological material found at crime scenes $(13,14)$. In 2003, Bauer et al. analyzed in vitro RNA stability over time and demonstrated a significant correlation between RNA degradation and storage time of bloodstain samples. These findings suggested the use of RNA as a potential indicator of the age of bloodstains (4). Moreover, previous studies by our laboratory have introduced the use of real-time reverse transcription PCR (Real-time RT PCR) as a method for measuring RNA degradation and estimating the age of bloodstains (5). This technique was based on the same concepts involved in radiocarbon dating 
(Carbon-14 dating), which is widely used in archaeological research as a means to determine the age of organic materials $(10,11,21,22)$.

Carbon-14 dating relies on a comparison between an observed number of unstable, radioactive carbon molecules $(\mathrm{C}-14)$ and the number of its more stable, non-radioactive isotope (C-12). Both C-14 and C-12 are naturally occurring molecules that are absorbed throughout any living organism's life. Unstable C-14 is constantly decaying into more stable N-14, however, because it is continuously absorbed while the organism is alive, the ratio between unstable and stable molecules remains constant. On the other hand, after death, the continuous decay of C-14 causes a gradual change in the ratio of C-14 to C-12. As a result, this change in ratio can be used to estimate the age of biological material. Unfortunately, the half- life of C-14 is over 5,000 years, thus, making the use of C-14 dating unreliable to Forensic Sciences $(11,22)$. However, the variation in decay levels of different types of RNA molecules follow a similar fashion as C14 decay; thus RNA degradation can be valuable in estimating age of biological stains in forensic cases $(10,11)$.

In studying the potential for using RNA decay to establish the age of bloodstains, Anderson et al. (2005) used quantitative real-time RT PCR in evaluating the rate of degradation of two different types of RNA molecules. 18S ribosomal RNA (18S rRNA) was chosen as the more stable molecule (analogous to $\mathrm{C}-12$ ), based on the assumption that the ribosome structure would confer a higher level of protection against degradation. In addition, $\beta$-actin messenger RNA (mRNA) was selected as the less stable counterpart (analogous to C-14) as it does not have the structural protection conferred from the ribosome, and therefore assumed to have a higher rate of decay $(5,10)$. Their results have shown that $18 \mathrm{~S}$ rRNA does indeed decay less rapidly than $\beta$-actin mRNA $(5,10)$. Moreover, Anderson et al. (2005) demonstrated that during a period 
of 150 days, the change in ratio between the two RNA types proceeded in a linear fashion, thus indicating a possible, more reliable method for estimating the time of deposition of biological samples $(5,10,12)$.

Later studies by our laboratory aimed to improve the accuracy and reliability of the technique described by Anderson et al. (2005) (11,21). Research has shown that transcriptional levels of mRNA vary among cell type, and changes in the functional activity of a cell results in an induction or blockage of gene expression $(3,11,17)$. As a consequence, the transcription rate of mRNAs will increase or decrease depending on the cell's physiological state $(5,11,12)$. Therefore, in order to eliminate potential inaccuracies that could be produced by different expression levels of the RNA target molecules, our laboratory re-designed the previous method to target two non-overlapping segments of different sizes located within the same RNA molecule. In the new protocol, a 300 base pair (bp) and an 89 bp amplicon segment was selected on the $\beta$-actin mRNA for comparing rates of decay and ultimately to estimate the age of dried bloodstains. This new assay's design followed the assumption that the larger segment, given its greater size, is more likely to be attacked by nucleases or other degradation factors, therefore conferring a higher rate of decay than the smaller segment (11) (see Figure 1). Thus, at time zero, when blood is first deposited, the mRNA molecule is expected to be un-degraded and the ratio between the amount of large and small segments should be equal. However, over time, the ratio is expected to change following a similar fashion as described by Anderson et.al (2005) (5, 10). The results of such experiments supported the predictions that larger amplicon segments have a faster rate of decay while small segments are more stable $(11,21)$. This confirms that the analysis of amplicons of different sizes from the same RNA molecule can be employed in a manner analogous to radiocarbon as a means of estimating the age of bloodstains $(5,10,11,21)$. 
The main objective of this thesis was to verify the environmental effects on RNA decay in bloodstains. In vivo RNA degradation occurs mainly by the action of RNases (17). However, RNA degradation in dried samples is a complex and not fully understood process, which could result in faulty interpretations of in vitro RNA decay $(11,12)$. It is thought that, in dried stains, the near complete absence of water inhibits the enzymatic activity, thus protecting the sample from degradation by RNase $(6,17)$. Therefore, it can be logically assumed that in vitro RNA degradation will depend on the environmental conditions at which the sample was exposed. Various studies have shown that factors such as temperature, humidity, ultraviolet (UV) light and $\mathrm{pH}$ indeed affect RNA decay $(5,10,12)$. In addition, it has also been demonstrated that RNA decay proceeds in a predictable fashion under controlled environmental conditions (4-6, 10-12). However, it is unrealistic to expect that in real crime scenes the biological sample will be exposed to a controlled, invariable environment. Therefore, it is imperative to understand the environmental effects on RNA decay, and more specifically, the effects of fluctuating temperatures and humidity in order to obtain a more accurate and reliable estimation of age of the stain.

\subsection{Accumulated Degree Days (ADD)}

It is commonly known that in many organisms, temperature plays a significant role on their developmental rate (23-25). As an example, plants, insects and other invertebrates require a certain amount of accumulated heat in order to change from one developmental stage to another throughout their life cycle $(23,25,26)$. Therefore, an increase in temperature accelerates metabolic rates, thereby speeding up biological processes such as seed germination in plants, or

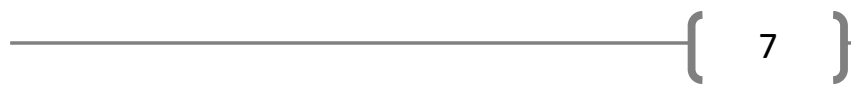


egg laying or insect development. An accumulated degree day (ADD) is a measurement of thermal units required to propel a biological process such as growth or development $(23,26,27)$. This physiological time model is widely used by ecologists to determine the effects of temperature on biological processes and, in agriculture, for monitoring crop development and pest management. Similarly, forensic entomologists apply the ADD model in determining the postmortem interval (PMI) through the observed stage of maggot development $(23,24,28)$.

In 2005, Megyesi et al. investigated the role of ADD on decomposed human remains. The results indicated that the combination of temperature and elapsed time accounted for more than $80 \%$ of the observed variation in human decomposition (23). Thus, the incorporation of ADD in PMI estimation can possibly result in a more accurate time determination, and therefore increases evidence strength and interpretation.

The objective of this pilot study was to incorporate ADD into RNA degradation analysis in order to take into account the temperature changes in a non-controlled environment for a more accurate and reliable method for estimating time of deposition of blood samples. 


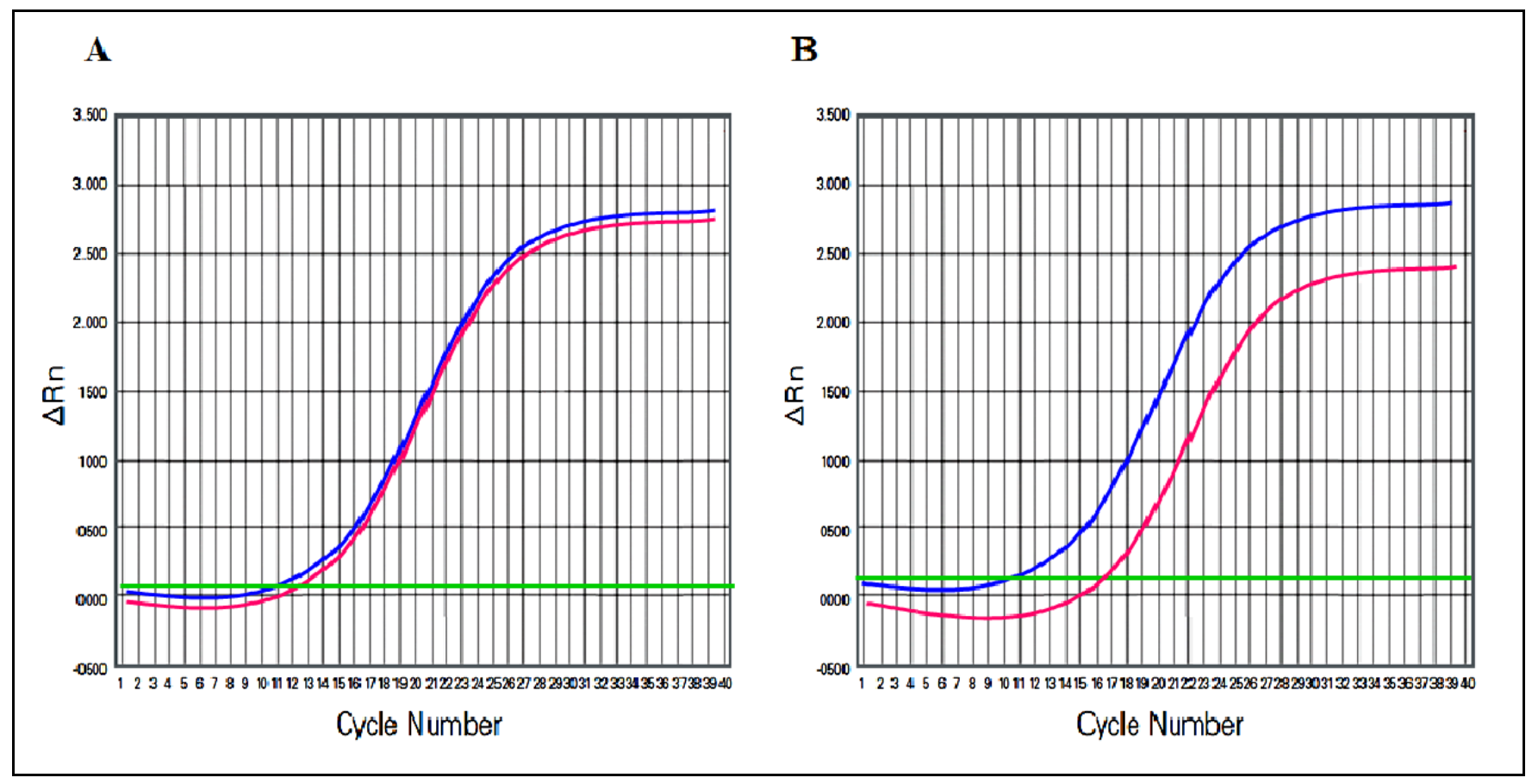

Figure 1: Amplification Plot of Real-time PCR. Blue line represents the amplification of the small fragment while the red line represents the large fragment amplification. Green line indicates the threshold used to determine the threshold cycle $\left(\mathrm{C}_{\mathrm{T}}\right)$ of both amplicons. The figure represents an example of the amplification of large and small amplicons used to establish RNA decay over time. At time zero, when blood is first deposited, the RNA molecule is expected to be un-degraded and the $\mathrm{C}_{\mathrm{T}}$ values for both large and small amplicons is expected to be similar (A). The large amplicon is more likely to be attacked by degradative factors. As a result, there is a decrease of the amount of intact target sequences, for the large segment, which then requires a larger number of cycles to reach exponential amplification. The increase of $\mathrm{C}_{\mathrm{T}}$ value is represented by a shift to the right of the amplification curve (B). 


\section{MATERIAL AND METHODS}

\subsection{Sample Preparation, Storage and Collection}

Venous blood was obtained by vein puncture, from one individual, using a non-coated BD Vaccutainer tube (Fisher Scientific, Pittsburgh, PA). Immediately after collection, $20 \mu 1$ aliquots were pipetted onto two separate $100 \%$ cotton sheets and air dried under a fume hood at room temperature for a period of approximately three hours. Next, four random spots, two from each sheet, were collected and RNA was isolated immediately to serve as a control (day 0). The sheets with the remaining samples were placed in two different rooms (attic and basement) of West Virginia University’s Crime House One to age. On days 5, 10, 20, 30, 60 and 90, three spots were collected from each room, placed in a $1.5 \mathrm{ml}$ nuclease free tube (Fisher Scientific, Foster City, CA) and taken to the lab for RNA isolation.

Our protocol was approved by the West Virginia University Institutional Review Board for the Protection of Human Research Subjects (IRB\#15833).

\subsection{Temperature and Humidity Monitoring}

Two HOBO U10 Temperature/Relative Humidity Data Loggers were used to monitor the temperature and humidity of the attic and basement of Crime House One. Temperature $\left({ }^{\circ} \mathrm{C}\right)$ and relative humidity $(\% \mathrm{RH})$ measurements were recorded daily in 30 minute intervals throughout the 90 day exposure/aging period. The retrieved data from both loggers was analyzed using the HOBOware Lite software, and the daily temperature and humidity as well as the maximum and 
minimum values for both variables were exported to an Excel file for further analysis (29).

Finally we compared the inside temperature and humidity data with an outside source, obtained from readings at the Morgantown Municipal Airport (MGW) in order to determine the possibility of using outside data to predict inside environment (30). This could be valuable information when analyzing and interpreting the data considering the low likelihood of having complete knowledge of the environmental conditions of a real crime scene.

\subsection{Multiplex Re-optimization}

The primers and probes for $\beta$-actin and 18S RNA were designed previously by our laboratory in order to establish a method for aging bloodstains. Initially, all primer sets were optimized for Applied Biosystem's 7700 Sequence Detection System. However, for this study, the amplification reaction was performed in Applied Biosystem's 7300 Real-Time PCR, and therefore new optimal primer concentrations and amplification conditions were determined in order to produce maximal PCR products (i.e. low $\mathrm{C}_{\mathrm{T}}$ values). The primer sequences and concentrations used for the amplification reaction of both $\beta$-actin mRNA and 18S rRNA are displayed on Table 1.

To ensure that the new amplification reaction parameters were optimal, an efficiency reaction test was performed (20,31-33). This helped to determine if both amplicons (the large and the small) presented similar amplification efficiencies. A serial dilution of the control cDNA $\left(1: 1,1: 2,1: 4,1: 8,1: 16,1: 32 ; \mathrm{cDNA}\right.$ :distilled water) was prepared and the difference in $\mathrm{C}_{\mathrm{T}}$ values for large and small amplicons $\left(\Delta \mathrm{C}_{\mathrm{T}}\right)$ compared throughout all dilutions $(20,32)$. Figure 2 ( $\beta$-actin) and Figure 3 (18S) show the plot of cDNA dilutions versus the $\Delta \mathrm{C}_{\mathrm{T}}$ values for both 
primer sets. A slope close to zero indicates similarity in the amplification efficiency of both small and large amplicons and therefore the optimization of the primer sets for the $2^{-\Delta C}$ T statistical method (32).

\subsection{RNA Isolation}

Total RNA isolation from the dried blood spots was performed using MRC TRIReagent ${ }^{\circledR}$ BD (34) . Seven hundred and fifty $\mu$ l of TRI Reagent ${ }^{\circledR}$ BD, $200 \mu$ l of UltraPure ${ }^{\mathrm{TM}}$ DNase/RNase-Free Distilled Water, $3 \mu$ polyacryl carrier and $20 \mu \mathrm{l}$ of $5 \mathrm{~N}$ acetic acid were added to a $1.5 \mathrm{ml}$ eppendorf tube containing one dried blood spot. The samples were then agitated using a vortex for approximately 15 seconds and incubated in a $50^{\circ} \mathrm{C}$ water bath for 10 minutes to allow for cell lysis. Afterward, phase separation was performed by adding $100 \mu$ of 1-bromo-3-chloropropane (BPC) to the cell lysates, agitating for 30 seconds, and incubating samples at room temperature for 10 minutes. The samples were then centrifuged at $12,000 \mathrm{xg}$ at $4^{\circ} \mathrm{C}$ for 15 minutes to allow maximum separation of the phases. Approximately $450 \mu$ of the top aqueous phase containing the RNA, was carefully removed, avoiding contamination by the organic phase, and then transferred to a new nuclease-free tube with $500 \mu$ l of cold isopropanol. The tubes were inverted 2 to 3 times and incubated for 10 minutes at room temperature. RNA precipitation was performed by centrifuging the samples at $12,000 \mathrm{x} g$ at $4^{\circ} \mathrm{C}$ for 10 minutes. The supernatant was discarded and the RNA pellet was washed with $1 \mathrm{ml}$ of $75 \%$ ethanol followed a final centrifugation at $12,000 \mathrm{xg}$ at $4^{\circ} \mathrm{C}$ for 5 minutes to re-pellet the isolated RNA. The ethanol was removed from the tubes that were then placed upside down for 5 minutes under a fume hood. This step was performed to eliminate the ethanol from the RNA pellets and to avoid 
possible PCR inhibition by ethanol contamination. Finally, $25 \mu \mathrm{l}$ of UltraPure ${ }^{\mathrm{TM}}$ DNase/RNaseFree Distilled Water was added to each tube and samples were incubated in a $55^{\circ} \mathrm{C}$ water bath for RNA resuspension (34).

\subsection{Genomic Screening}

In the Real-time RT-PCR method, demonstration that the detected signal comes exclusively from amplification of RNA target, and not from DNA contamination, is a crucial step for the assay validation $(33,35-38)$. Therefore, in order to determine potential DNA contamination in the isolated RNA samples, a genomic screening was performed using a DNAspecific primer/probe set (GAPNT 201) previously designed and used by our laboratory. The set was designed to detect a non-transcribed region of the human housekeeping gene glyceraldehyde-3-phosphate dehydrogenase (GAPDH) $(39,40)$.

The genomic screening reaction contained a final concentration of 1X TaqMan® Universal PCR Master Mix, 900 nM of GAPNT201 forward and reverse, 250 nM of GAPNT201 probe, $2.375 \mu 1$ of UltraPure ${ }^{\mathrm{TM}}$ DNase/RNase-Free Distilled Water, and $5 \mu 1$ of isolated total RNA sample. The samples were then pulse-centrifuged and placed into an Applied Biosystems 7300 Real-time under the following conditions: 1 cycle at $50^{\circ} \mathrm{C}$ for 2 minutes, 1 cycle at $95^{\circ} \mathrm{C}$ for 10 minutes, and 40 cycles alternating between $95^{\circ} \mathrm{C}$ for 15 seconds and $60^{\circ} \mathrm{C}$ for 1 minute. In addition, a positive control containing male genomic DNA and a negative control with nuclease free water were included in every real time run. Tables 1 and $\mathbf{2}$ display the primer and probe sequences, final concentration and reagents used on the genomic screening reaction. 


\section{6 cDNA Synthesis}

Following isolation, the total RNA samples were subjected to reverse transcription by Reverse Transcriptase Polymerase Chain Reaction (RT-PCR) and RNA molecules were converted to complementary DNA (cDNA). Reverse transcription was performed using the Applied Biosystems TaqMan® Gold RT-PCR Kit $(35,41)$. The reverse transcription reaction was carried out in $0.5 \mathrm{ml}$ tubes containing $28.5 \mu \mathrm{l}$ of reverse transcription master mix (1X TaqMan® RT Buffer, $5.5 \mathrm{mM}$ magnesium chloride, $500 \mu \mathrm{M}$ of each dATP, dCTP, dGTP and $\mathrm{dTTP}$ as well as $2.5 \mu \mathrm{M}$ random hexamers), $1.0 \mu \mathrm{l}$ of RNase inhibitor $(0.4 \mathrm{U}), 1.25 \mu \mathrm{l}$ of Multiscribe Reverse Transcriptase (1.875U), and $20 \mu$ of total RNA samples. The tubes containing the reverse transcription reaction were pulse-centrifuged and placed in a Techne Touchgene Gradient Thermocycler set at the following conditions: 1 cycle at $25^{\circ} \mathrm{C}$ for 10 minutes, 1 cycle at $48^{\circ} \mathrm{C}$ for 30 minutes, 1 cycle at $90^{\circ} \mathrm{C}$ for 5 minutes, and a final hold at $4^{\circ} \mathrm{C}$. The end of the reaction produced single-stranded cDNA samples that were then stored at $-80^{\circ} \mathrm{C}$ until quantitative PCR amplification (qPCR).

\subsection{Real-Time Polymerase Chain Reaction}

The single-stranded cDNA samples were submitted to two different Multiplex Real-time PCR reactions to amplify two segments of different size (the large and small amplicons) from both $\beta$-actin and 18S RNA targets. Table 2 displays all reagents and their respective final concentrations used in the amplification master mixes. To determine amplification and quantification by qPCR, each sample was run using the Applied Biosystems 7300 Real-Time 
PCR under the following conditions: 1 cycle at $50^{\circ} \mathrm{C}$ for 2 minutes, 1 cycle at $95^{\circ} \mathrm{C}$ for 10 minutes, and 40 cycles alternating between $95^{\circ} \mathrm{C}$ for 15 seconds and $60^{\circ} \mathrm{C}$ for 2.5 minutes (for annealing and extension of the primers). To increase accuracy, the samples in both $\beta$-actin and 18S amplification reactions were performed in replicates of two.

\subsection{Statistical Analysis}

\subsubsection{Accumulated Degree Days (ADD) Calculation}

The ADD values were incorporated in our simple linear regression model in order to obtain a more accurate prediction of time of deposition of bloodstains. The positive correlation between temperature and degradation rate requires that, when trying to estimate PMI, the environmental temperature must be taken into account. The standard technique used by forensic entomologists to deduce maggot growth and development is known as ADD and can be calculated by several methods $(23,25)$. For this pilot study we chose the simplest method to calculate ADD, known as the rectangle method, which assumes the following formula:

$$
\mathrm{ADD}=\left(\left(\mathrm{T}_{\mathrm{MAX}}+\mathrm{T}_{\mathrm{MIN}}\right)_{\text {per day }}-\mathrm{T}_{\mathrm{THRESHOLD}}\right)
$$

Where, $\mathrm{T}_{\mathrm{MAX}}$ and $\mathrm{T}_{\mathrm{MIN}}$ are maximum and minimum daily temperatures while $\mathrm{T}_{\text {THRESHOLD }}$ is the minimum temperature at which the biological process occurs. Considering that most biological processes are severely inhibited by extreme low temperatures, we used a minimum threshold of $0^{\circ} \mathrm{C}$ for our ADD calculations $(23,24)$. Finally, ADD values were calculated by adding all daily temperatures above $0^{\circ} \mathrm{C}$, from day 0 to each collection day $(0,5,10,20,30,60$, 
and 90). Any day with a temperature below the threshold was considered as $0^{\circ} \mathrm{C}(23,24)$. For graphing purposes, the ADD values were converted to a log10 scale. Table 3 displays the ADD calculated for each sample isolation day from both rooms as well as the transformed values.

\subsection{2 $2^{-4 C}$ Statistical Method}

Real-Time RT PCR, also known as quantitative PCR (qPCR) is a fluorescence-based technique that combines reverse transcription with real-time PCR methods. This PCR variation assay allows for an elegant way to simultaneously amplify and quantify target RNA sequences of interest within a sample and has been extensively used in gene expression studies $(20,42,43)$. This technique incorporates an oligonucleotide probe containing a 5'-reporter and a 3'-quencher dyes, and takes advantage of the 5' nuclease activity of AmpliTaq ${ }^{\circledR}$ Gold polymerase enzyme $(20,31,35,44-46)$. The fluorescence of the 5 '-reporter is hindered by the 3 '-quencher while the probe is intact. However, if probe/target hybridization occurs during the amplification cycle, the $5^{\prime} \rightarrow 3^{\prime}$ exonuclease activity of the enzyme will lead to cleavage and degradation of the probe. Thus when the reporter and quencher are released from the target, and are no longer close to each other, fluorescence is emitted from the reporter dye and is captured by the real time thermo cycler $(20,31,35,37,46)$. Therefore, the detection and quantification of the fluorescence emitted in each cycle allows for monitoring of product accumulation, which is generated continuously during cycling $(44,46)$. Furthermore, the fluorescence signal has a positive correlation with the amount of PCR product generated by the amplification reaction (Figure 1) $(43,46)$. 
The cycle number at which there is an exponential increase in fluorescence occurs when the amount of the product being generated is equal to the amount of initial template $(10,41,47$, 48). At the exponential phase, the fluorescence emitted by the breakdown of the probes crosses the background noise threshold. This point is referred to as the $\mathrm{C}_{\mathrm{T}}$ value and indicates the beginning of the exponential amplification of the cDNA $(31,32,41,47,49)$.

The relative quantification of small and large segments was performed using Applied Biosystem's Sequence Detection Software Version 1.3. The $\mathrm{C}_{\mathrm{T}}$ values for each sample were determined and exported into Microsoft Excel. Next, the $2^{-\Delta C}$ Tethod was used to calculate the relative changes in the amplification of the large and small segments. The difference between $C_{T}$ values for large and small segments is designated by $\Delta \mathrm{C}_{\mathrm{T}}$ for each data point $(32,50)$. The ratio of small and large segments, $\mathrm{N}$, was determined by the equation, $\mathrm{N}=2^{-\Delta \mathrm{C}}$. This equation accounts for the exponential amplification of the Real-Time reaction $(10,32,50)$. Finally, the $\mathrm{N}$ values for all the data were plotted against the $\log 10 \mathrm{ADD}$ of each sample collection interval, generating a standard curve. The standard curve can potentially be used to estimate the time of deposition for biological samples found at a crime scene by extrapolating the corresponding time from the sample's observed $\mathrm{N}$ value. 
Table1 Primers and Probes sequences and estimated amplicon size. The GAPDH gene was used to assess for genomic contamination of the isolated RNA samples. Two regions of different sizes on both $\beta$-actin and $18 \mathrm{~S}$ RNA were used for the RNA quantification (qPCR).

\begin{tabular}{|c|c|c|c|c|}
\hline Target & \multicolumn{2}{|c|}{ Primer/Probe Name } & Sequence & Amplicon Size \\
\hline 苞 & GAPNT201 & $\begin{array}{l}\text { FP } \\
\text { RP } \\
\text { VIC }\end{array}$ & $\begin{array}{c}\text { 5'-TGTTTCATCCAAGCGTGTAAG-3' } \\
\text { 5'-TGTTTCATCCAAGCGTGTAAG-3' } \\
\text { 5'-GTCCTGGGAACCAGCACCGATCAC3-' }\end{array}$ & $180 \mathrm{bp}$ \\
\hline \multirow{2}{*}{ 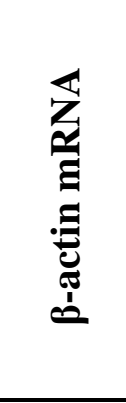 } & BAA & $\begin{array}{l}\text { FP } \\
\text { RP } \\
\text { FAM }\end{array}$ & $\begin{array}{c}\text { 5'-CTTCAACACCCCAGCCATGT-3' } \\
\text { 5'-CTCTTGCTCGAAGTCCAGGG-3' } \\
\text { 5'-CTGTGCTATCCCTGTACGCCTCTGGC-3' }\end{array}$ & $300 \mathrm{bp}$ \\
\hline & BA4 & $\begin{array}{l}\text { FP } \\
\text { RP } \\
\text { VIC }\end{array}$ & $\begin{array}{c}\text { 5'-TTCCAAATATGAGATGCATTGT-3' } \\
\text { 5'-GGACTGGGCCATTCTCCTTAG-3' } \\
\text { 5'-AAGTCCCTTGCCATCCTAAAAGCCACC-3' }\end{array}$ & $89 \mathrm{bp}$ \\
\hline \multirow{2}{*}{ 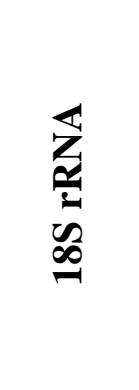 } & $18 \mathrm{SA}$ & $\begin{array}{l}\text { FP } \\
\text { RP } \\
\text { FAM } \\
\end{array}$ & $\begin{array}{c}\text { 5'-TTCGGAACTGAGGCCATGAT-3' } \\
\text { 5'-CATGCCAGAGTCTCGTTCGTT-3' } \\
\text { 5'-CATTCGTATTGCGCCGCTAGAGGTG-3' }\end{array}$ & $501 b p$ \\
\hline & $18 \mathrm{SB}$ & $\begin{array}{l}\text { FP } \\
\text { RP } \\
\text { VIC }\end{array}$ & $\begin{array}{c}\text { 5'-CGGAGAGGGAGCCTGAGAA-3' } \\
\text { 5'-CTCCAATGGATCCTCGTTAAAGG-3' } \\
\text { 5'- CGGCTACCACATCCAAGGAAGGCA-3' }\end{array}$ & $171 \mathrm{bp}$ \\
\hline
\end{tabular}




\section{RESULTS}

\subsection{Multiplex Re-Optimization}

New optimal primer concentrations and amplification conditions were determined in order to produce maximal PCR products using the Applied Biosystem's 7300 Real-Time PCR

thermo cycler (see Table 1 and 2). In order to validate the $2^{-\Delta C}$, the amplification efficiency of the multiplexed large and small amplicons was performed. A slope with an absolute value close to zero indicates similarity in the efficiency of both amplicons (32). Figure 2 displays the result for the amplification efficiency test of $\beta$-actin mRNA multiplex. The plot of the $\Delta \mathrm{C}_{\mathrm{T}}\left(\mathrm{C}_{\mathrm{T}}\right.$, FAM $\mathrm{C}_{\mathrm{T}, \mathrm{vIC}}$ ) versus the log cDNA dilutions was fit using least-squares linear regression analysis and the slope of the line is -0.0215 . Similarly, the amplification efficiency for the $18 \mathrm{~S}$ rRNA multiplex generated a slope of 0.0032 (see Figure 3). Therefore, the assumption is held in both cases and the $2^{-\Delta C_{T}}$ statistics could be used for our data analysis.

\subsection{Genomic Screening}

Given its sensibility, real-time amplification can detect extremely small amounts of target sequence and, in theory; even a single copy could produce an amplification signal. Accordingly, DNA carryover during RNA isolation, which is a common event, is a major concern when performing RNA quantification $(11,33,36,38)$. In order to determine if the amplification signals resulted solely from RNA targets, a genomic screening was performed on all samples using realtime PCR with a DNA-specific primer/probe set for the GAPDH housekeeping gene. The lower 
the $\mathrm{C}_{\mathrm{T}}$ values, the higher the DNA contamination. Because the amplification reaction consisted of 40 cycles, values above 35 were considered background noise (31). GAPNT 201 reaction did not produce any amplification signal bellow $35-\mathrm{C}_{\mathrm{T}}$ for any of the isolated RNA samples (data not shown).

\subsection{Temperature and Relative Humidity}

Temperature $\left({ }^{\circ} \mathrm{C}\right)$ and relative humidity $(\% \mathrm{RH})$ were recorded at 30 minute intervals throughout the entire exposure period. Figure 10 shows the average \pm standard deviation $(\mathrm{N}=$ 48), maximum and minimum temperature data recorded from attic and basement environments at WVU's Crime House One. The trend shown in Figure 10-A corresponds to the high temperature fluctuation on the attic "environment." On the other hand, the basement (Figure 10-B) demonstrated a smooth trend as a consequence of more stable temperatures during the 90 day study.

Average $\pm \mathrm{SD}(\mathrm{N}=48)$, maximum and minimum humidity data are displayed in Figure 11. The figure illustrates that the behavior of the relative humidity in both rooms contrasted with that of the temperature. The results show fairly constant humidity values in the attic while the basement displayed high fluctuations (see Figure 11 A-B). The results also show that the basement had the lowest daily humidity values, never exceeding $50 \% \mathrm{RH}$.

Figure 12 illustrates the comparison of average temperatures between Morgantown Airport (MGW) versus both attic and basement. Figure 12-A results indicate a low correlation between attic and airport daily average temperatures $\left(\mathrm{R}^{2}=0.67\right)$. However, the data did not show any association between airport and basement temperatures $\left(R^{2}=0.0014\right)$ during the 
exposure period. Moreover, comparisons of the daily relative humidity data also showed no association of the MGW average \% RH with any of the indoor environments. $\left(\mathrm{R}^{2}\right.$ Attic $=0.0607$; $\mathrm{R}^{2}$ Basement $=0.0001 ; \mathrm{N}=90$ ) (see Figure 13). Complete temperature and relative humidity data for the 90 days interval can be viewed in Appendix I.

\subsection{RNA decay vs. ADD}

RNA decay over time was detected by Real-time RT PCR amplification of two fragments of different sizes on $\beta$-actin and 18S RNAs. The linear regression model for RNA decay analysis was determined by plotting the difference in amplification of large and small amplicons $\left(2^{-\Delta \mathrm{C}}\right)$ versus ADD in order to take into account the exponential amplification of the PCR reaction and accurately fit the data into the linear model. Transformed ADD values for attic, basement and airport data are shown on Table 3 .

Figures 4 and 7 illustrate the results for the bloodstain samples aged at the basement environment of Crime House One. The results show a negative correlation between the change in $\Delta \mathrm{C}_{\mathrm{T}}$ values $\left(2_{\mathrm{T}}^{-\Delta \mathrm{C}}\right)$ and time (Log $\left.10(\mathrm{ADD})\right)$ on both $\beta$-actin and $18 \mathrm{~S}$ target RNAs (see Figures

4 and 7). Respectively, the correlation coefficients ( $R^{2}$ values) of 0.9115 and 0.9036 suggest a good fit of the data to the linear regression model. On the other hand, the results from the samples exposed in the attic showed very low $\mathrm{R}^{2}$ values, indicating no correlation between $\beta$ $\operatorname{actin}\left(\mathrm{R}^{2}=0.3917\right)$ or $18 \mathrm{~S}\left(\mathrm{R}^{2}=0.3698\right) \mathrm{RNA}$ decay and time elapsed (see Figures 5 and 8 ).

Finally, the sample amplification values were plotted against the exposure time (Days). As seen in Figures 6 and 9, when using day instead of ADD, there was a change in the regression model. The results also demonstrate a decrease in fitness of the data for $\beta$-actin 
mRNA decay analysis of the basement samples $\left(\mathrm{R}^{2}=0.817\right)$ and a reduction of almost $50 \%$ of the correlation coefficient for the $18 \mathrm{~S}$ rRNA decay analysis $\left(\mathrm{R}^{2}=0.486\right)$ (see Figures 6 and 9). 


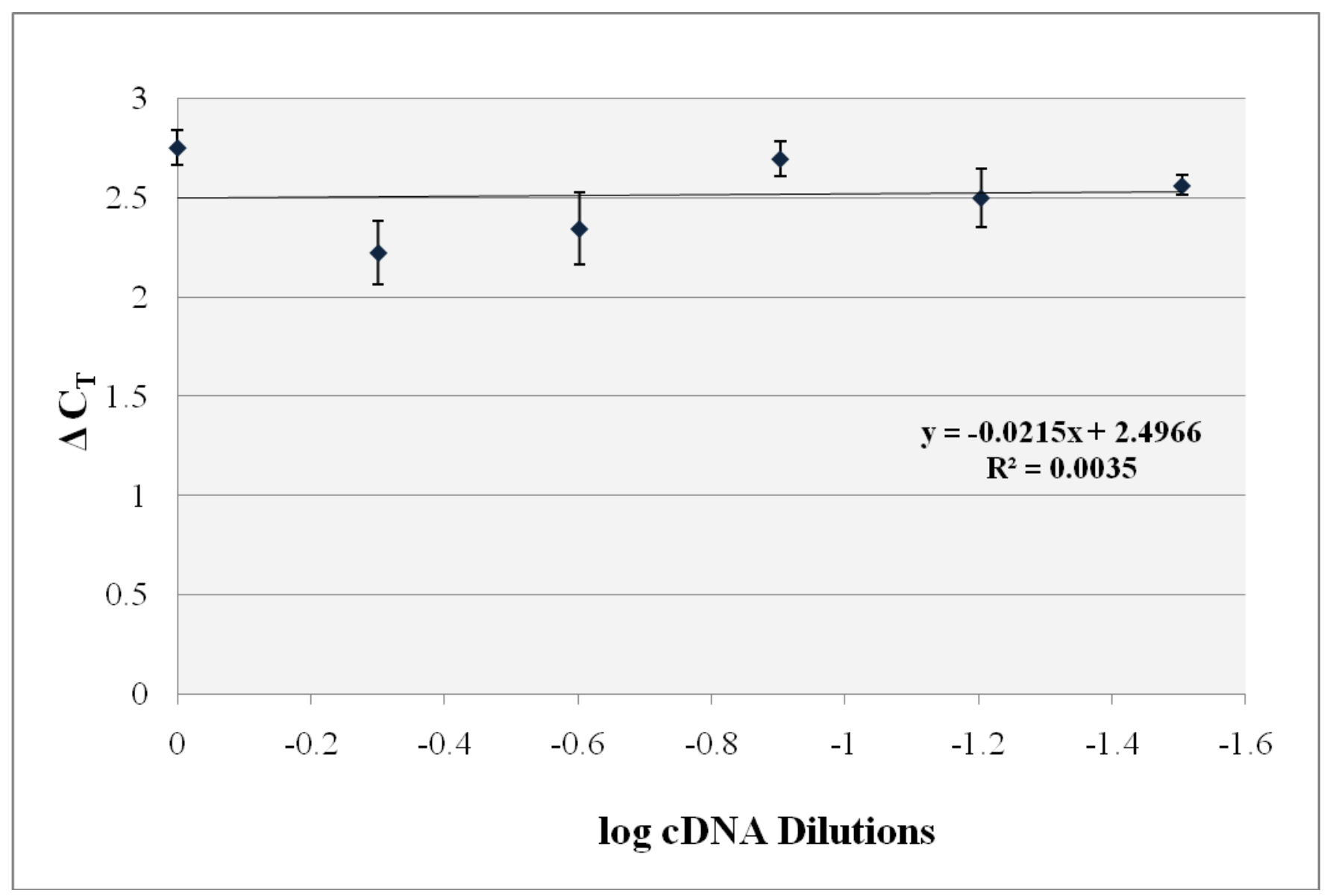

Figure 2: Amplification Efficiency of $\beta$-actin mRNA Multiplex. The efficiency of amplification of large (BAA) and small (BA4) amplicons for $\beta$-actin mRNA was determined by Real-time RT PCR. cDNA control was synthesized by reverse transcriptase technique followed by a dilution series. The $\mathrm{Ct}$ values for BAA and BA4 in each dilution were obtained and $\Delta \mathrm{C}_{\mathrm{T}}\left(\mathrm{C}_{\mathrm{T}, \mathrm{BAA}}-\mathrm{C}_{\mathrm{T}, \mathrm{BA} 4}\right)$ for each dilution was calculated. A plot of log cDNA dilutions versus $\Delta \mathrm{C}_{\mathrm{T}}$ with an absolute value of the slop close to zero represents an approximately equal amplification efficiency of large and small amplicons. The slope of the line generated is 0.0215 , thus indicating the similarity in BAA:BA4 multiplex amplification and, therefore, validating our assay to be used with the $2^{-\Delta \mathrm{CT}}$ statistical method. 


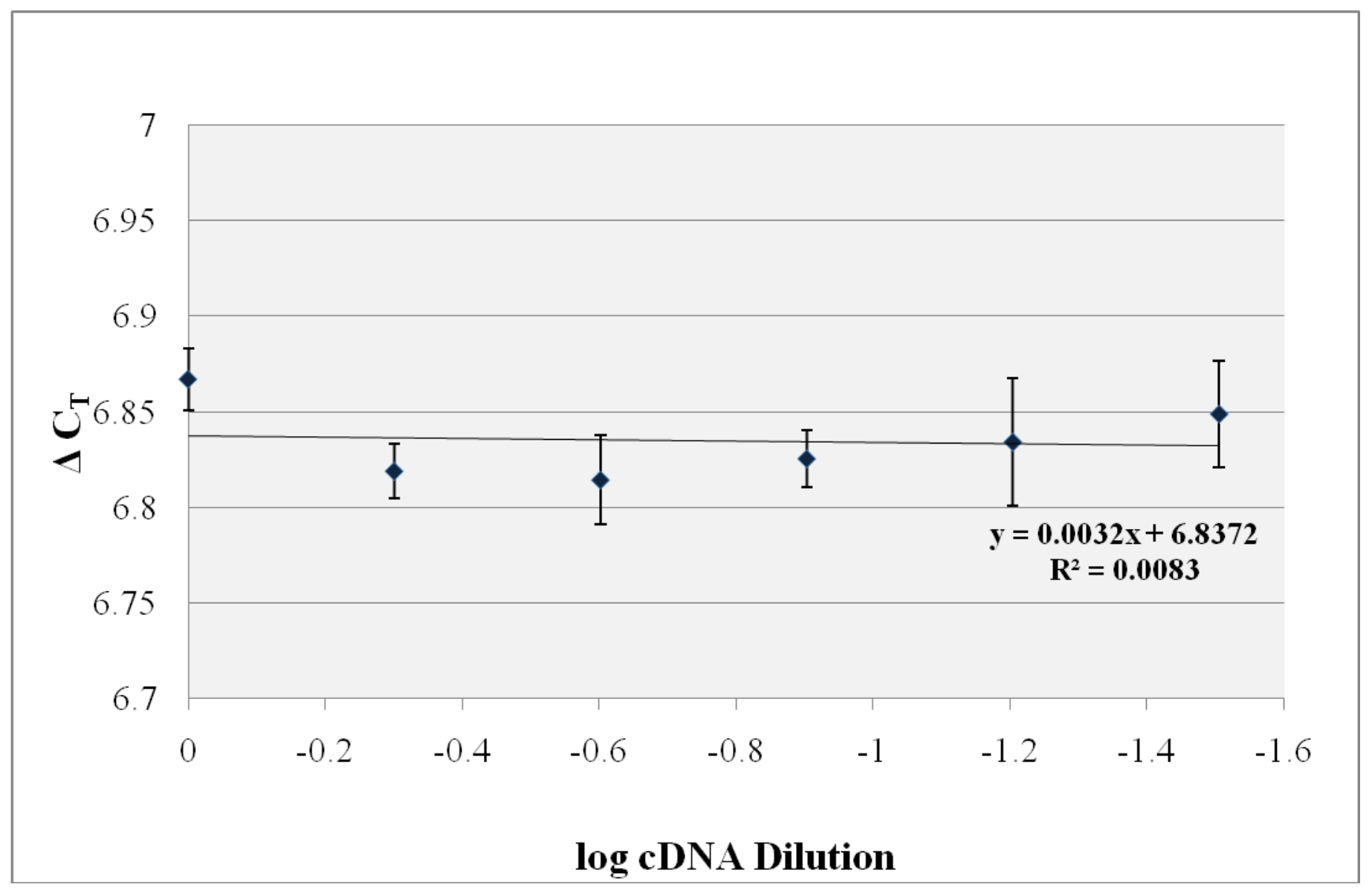

Figure 3: Amplification Efficiency of 18S rRNA Multiplex. The efficiency of amplification of large (18SA) and small (18SB) amplicons for 18S rRNA was determined by Real-time RT PCR. cDNA control was synthesized by reverse transcriptase technique followed by a dilution series. The $\mathrm{Ct}$ values for large and small amplicons in each dilution were obtained and $\Delta \mathrm{C}_{\mathrm{T}}\left(\mathrm{C}_{\mathrm{T}, \mathrm{BAA}}-\mathrm{C}_{\mathrm{T}, \mathrm{BA} 4}\right)$ values for each dilution calculated. A plot of $\log$ cDNA dilutions versus $\Delta \mathrm{C}_{\mathrm{T}}$ with an absolute value of the slop close to zero represents an approximately equal amplification efficiency of large and small amplicons. The slope of the line generated is 0.0083 , thus indicating the similarity in our 18SA:18SB multiplex amplification and validating our assay to be used with the $2^{-\Delta \mathrm{CT}}$ statistical method. 


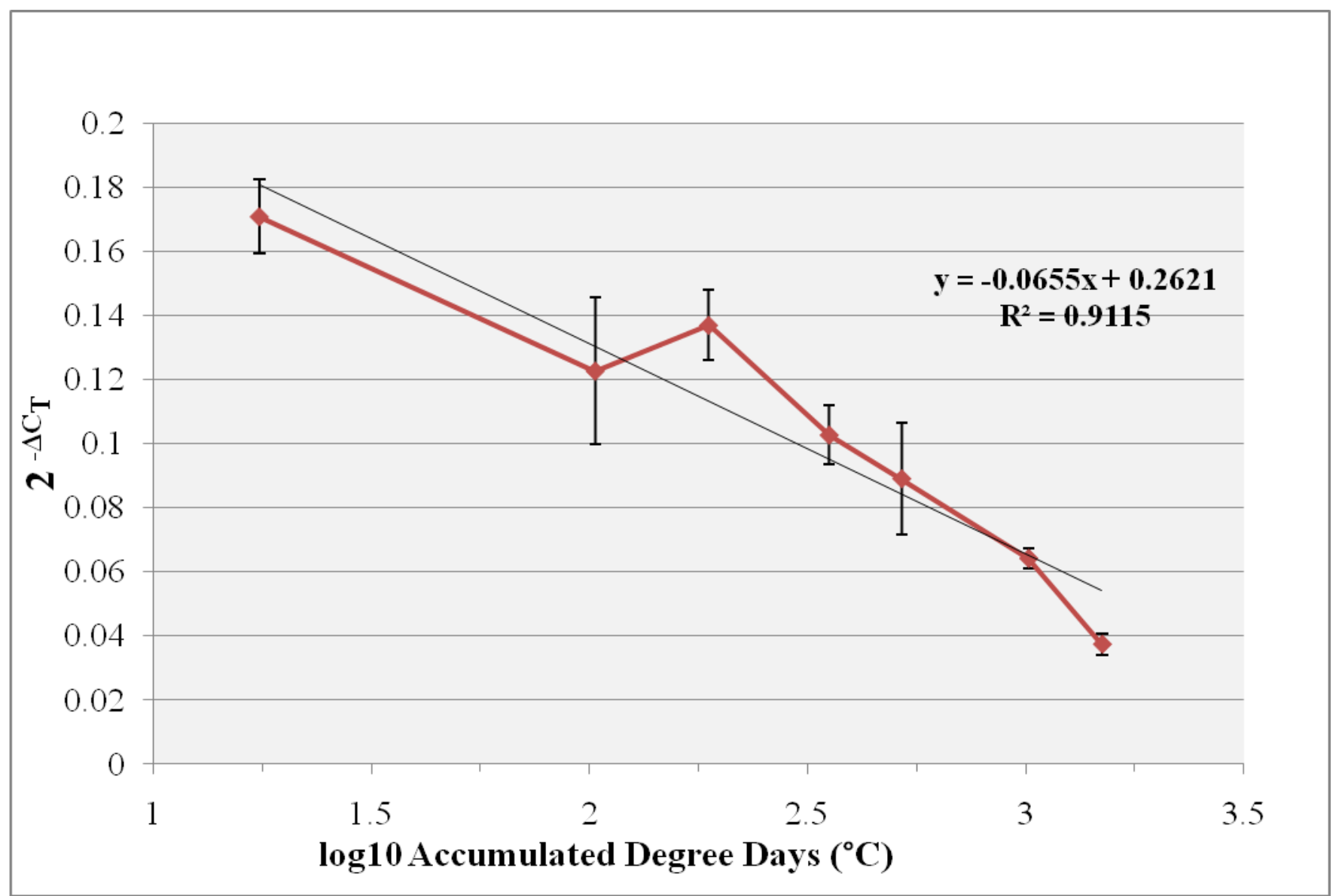

Figure 4: $\boldsymbol{\beta}$-actin mRNA Degradation Over-time - Basement. Results are expressed as the average $2^{-}$ ${ }_{\mathrm{T}} \pm \mathrm{SE}$. cDNA samples obtained from dried bloodstains in a 90 days exposure period were subjected to real-time RT PCR and the large (BAA) and small (BA4) fragments of the $\beta$-actin mRNA were amplified. The average values for large (300bp) minus small (89bp) amplicons versus time (ADD) are presented. To account for the exponential amplification of Real-time RT PCR, the accumulated degree days were transformed to exponential values. The $\mathrm{R}^{2}$ values $\left(\mathrm{R}^{2}=0.9115\right)$ indicate a negative correlation between change in mRNA levels $\left(2^{-\Delta \mathrm{C}}\right)$ and time (Log 10(ADD)) 


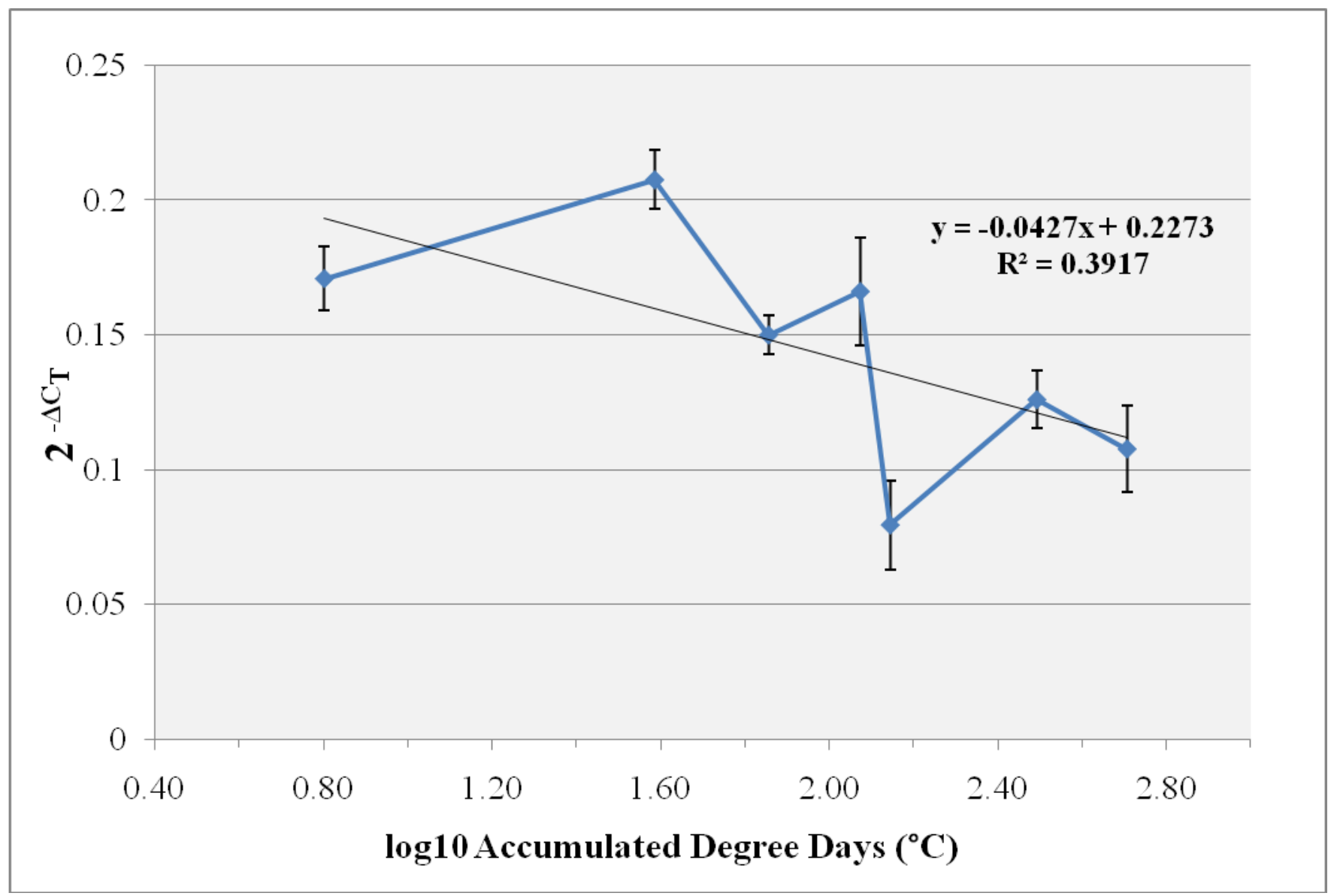

Figure 5: $\boldsymbol{\beta}$-actin mRNA Degradation Over-time - Attic. Results are expressed as the average $2^{-\Delta \mathrm{C}} \pm \mathrm{SE}$. cDNA samples obtained from dried bloodstains in a 90 days exposure period were subjected to real-time RT PCR and the large (BAA) and small (BA4) fragments of the $\beta$-actin mRNA were amplified. The average values for large (300bp) minus small (89bp) amplicons versus time (ADD) are presented. To account for the exponential amplification of Real-time RT PCR, the accumulated degree days were transformed to exponential values. No correlation between change in mRNA levels $\left(2^{-\Delta \mathrm{C}}\right.$ ) and time (Log 10(ADD)) was observed for the bloodstains exposed on the attic at Crime House One $\left(\mathrm{R}^{2}=0.3917\right)$. 


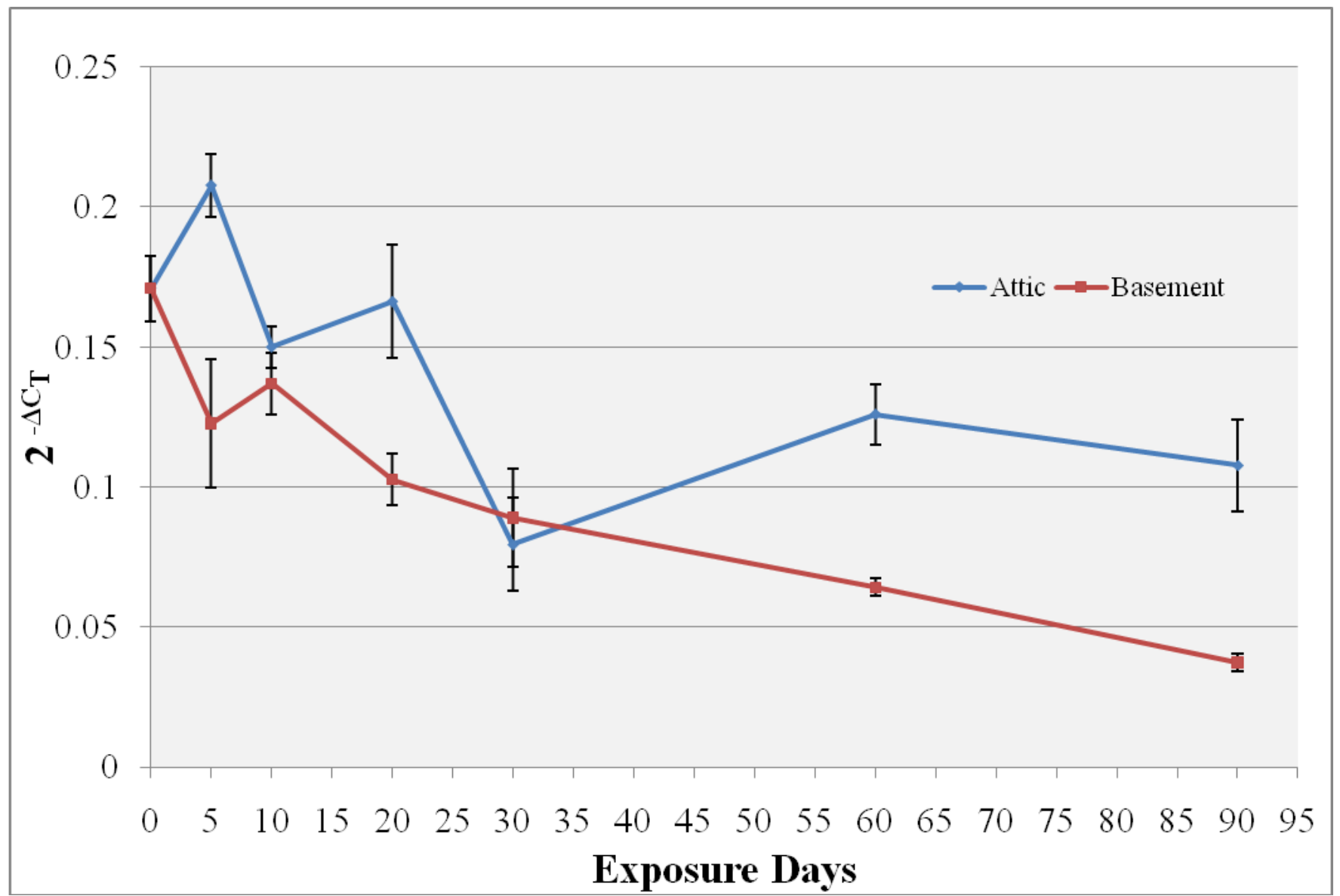

Figure 6: $\boldsymbol{\beta}$-actin mRNA Degradation Over-time. Results are expressed as the mean \pm SE. For the amplification reaction, BAA probe (300bp amplicon) was labeled with FAM $^{\mathrm{TM}}$ while BA4 (89bp amplicon) was labeled with VIC ${ }^{\mathrm{TM}}$. The figure illustrates a negative correlation between RNA decay and time for bloodstains exposed in the basement. However, the data generated by the samples exposed in the attic indicates an unpredictable RNA decay. The $\mathrm{R}^{2}$ coefficient obtained from least-square linear regression model were $\mathrm{R}^{2}=0.411$ and $\mathrm{R}^{2}=0.871$ for bloodstains exposed on attic and basement respectively. 


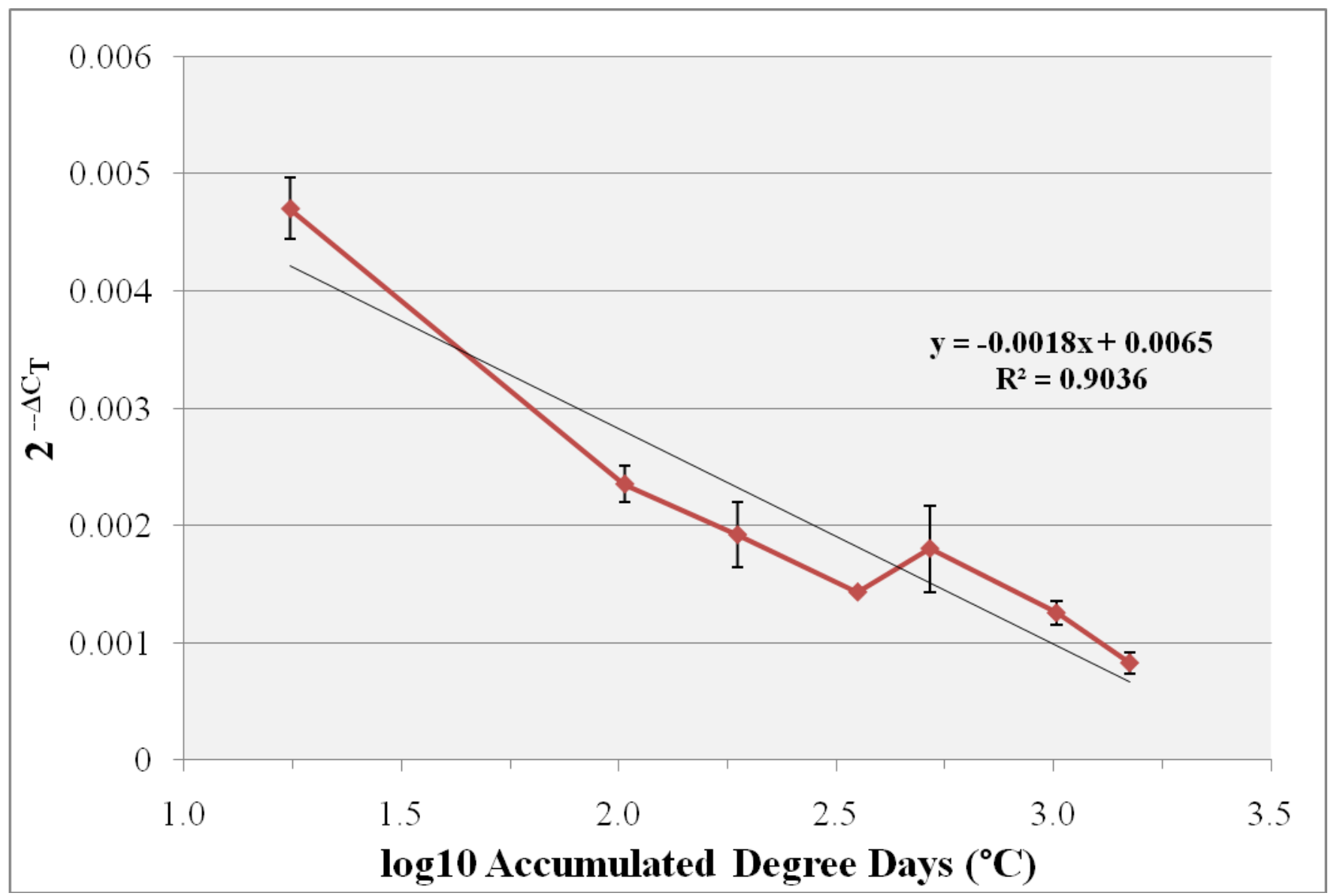

Figure 7: 18S rRNA Degradation Over-time - Basement. Results are expressed as the average $2^{-\Delta C_{T}} \pm$ SE. cDNA samples obtained from dried bloodstains in a 90 days exposure period were subjected to realtime RT PCR and the large (18SA) and small (18SB) fragments of the $18 \mathrm{~S}$ rRNA were amplified. The average values for large (501bp) minus small (171bp) amplicons versus time (ADD) are presented. To account for the exponential amplification of Real-time RT PCR, the accumulated degree days were transformed to exponential values. The $R^{2}$ value $\left(R^{2}=0.9036\right)$ indicates a negative correlation between relative change in rRNA levels $\left(2^{-\Delta \mathrm{C}}\right)$ and time (Log 10(ADD)). 


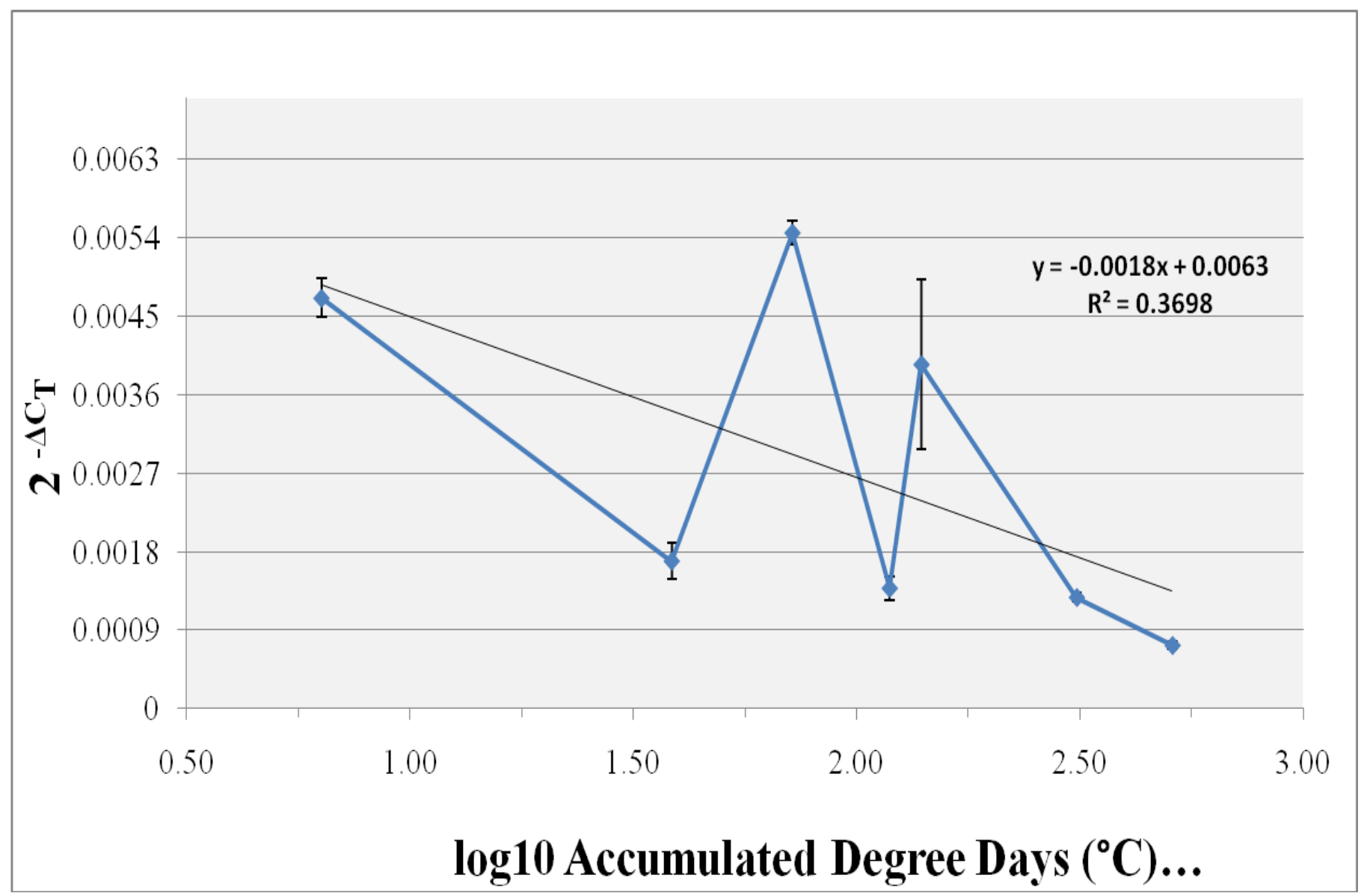

Figure 8: 18S rRNA Degradation Over-time - Attic. . Results are expressed as the average $2_{\mathrm{T}}^{-\Delta \mathrm{C}} \pm$ SE. cDNA samples obtained from dried bloodstains in a 90 days exposure period were subjected to realtime RT PCR and the large (18SA) and small (18SB) fragments of the $18 \mathrm{~S}$ rRNA were amplified. The average values for large (501bp) minus small (171bp) amplicons versus time (ADD) are presented. To account for the exponential amplification of Real-time RT PCR, the accumulated degree days were transformed to exponential values. No correlation between rRNA decay and time was observed for the bloodstains exposed on the attic of Crime House One $\left(R^{2}=0.3698\right)$. 


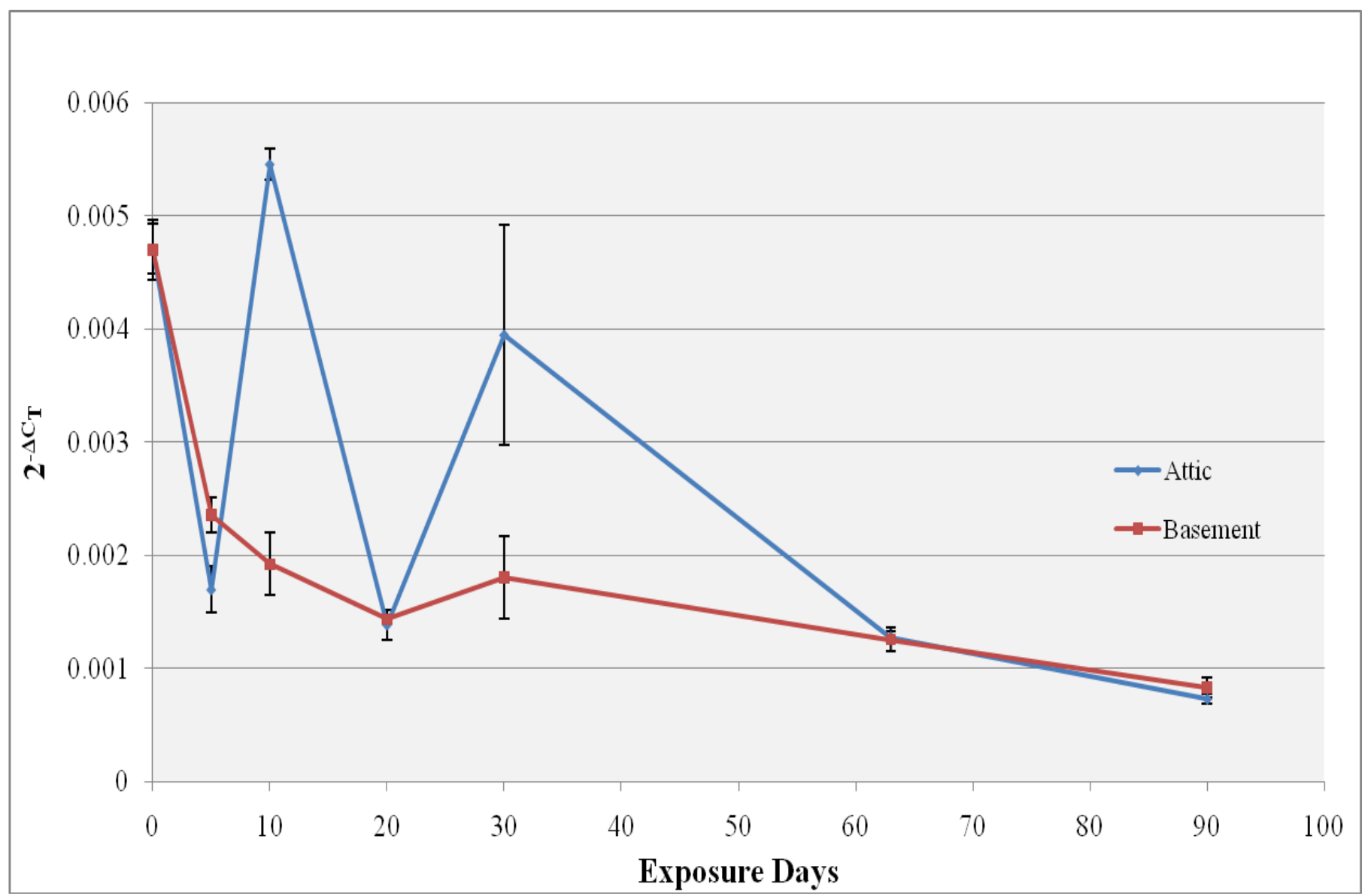

Figure 9: 18S rRNA Degradation Over-time. Results are expressed as the mean $\pm \mathrm{SE}$. For the amplification reaction, 18SA probe was labeled with FAM $^{\mathrm{TM}}$ dye, while $18 \mathrm{SB}$ was labeled with VIC $^{\mathrm{TM}}$. The figure illustrates a negative correlation between RNA decay and time for bloodstains exposed on the basement. However, the data generated by the samples exposed on the attic indicate an unpredictable RNA decay. The $\mathrm{R}^{2}$ coefficient obtained from least-square linear regression model were $\mathrm{R}^{2}=$ 0.401 and $R^{2}=0.486$ for bloodstains exposed on attic and basement respectively 

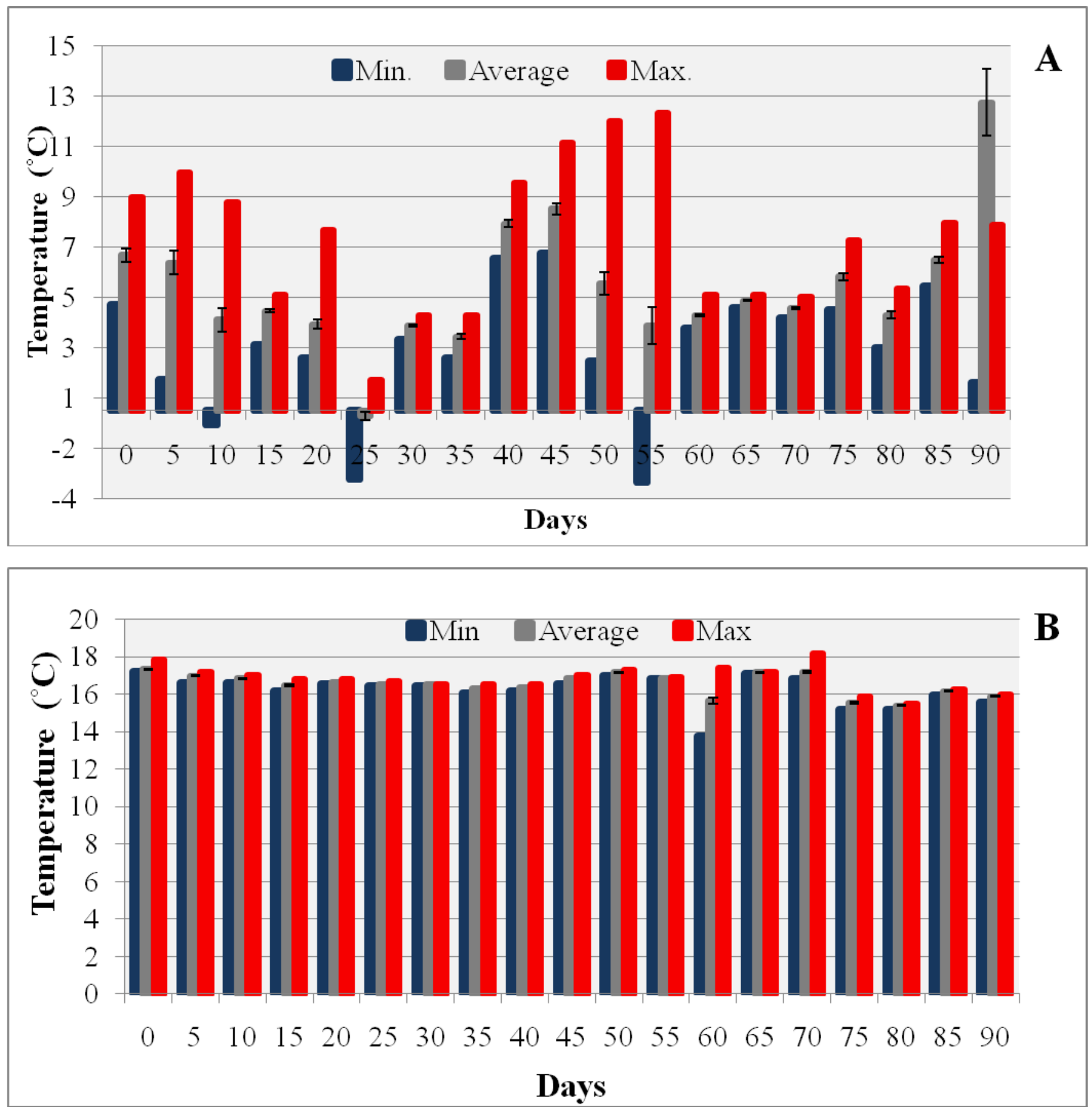

Figure 10: Crime House One Temperature Data. HOBO U10 Temperature/Relative Humidity Data Loggers were used to record data every $30 \mathrm{~min}$. The figure illustrates a high fluctuation of temperature in the attic (A) while the basement presented more stable temperature throughout the exposure period $(\mathbf{B})$. Results are expressed as Max. Min. and Average \pm SD $(n=48)$. 

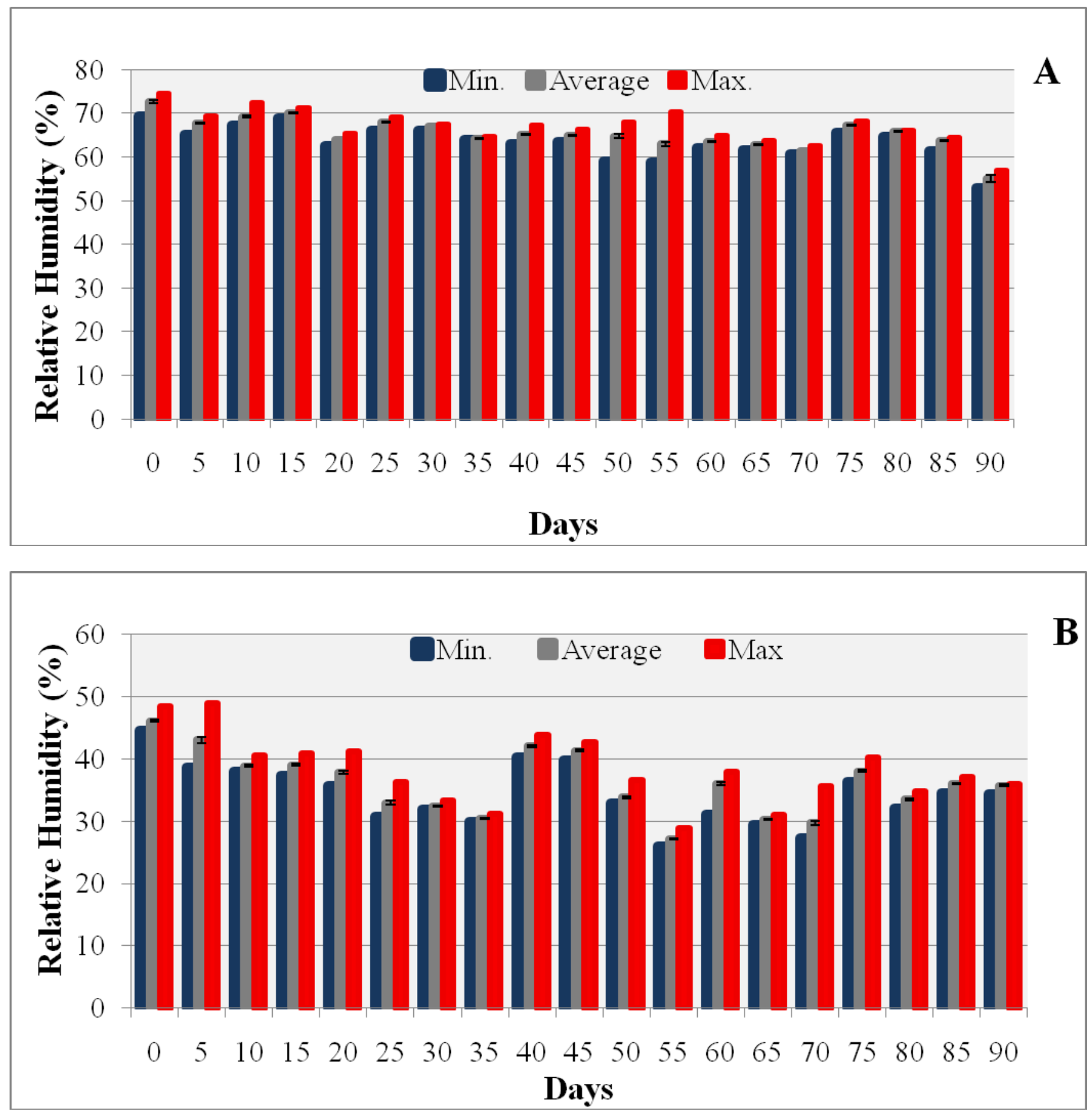

Figure 11: Crime House One - Relativity Humidity Data. Results are expressed as Max. Min. and Average \pm SD $(\mathrm{n}=48)$. HOBO U10 Temperature/Relative Humidity Data Loggers were used to record data every $30 \mathrm{~min}$. The Figure demonstrates a low variation in the relative humidity (\%) at the attic (A), and a relatively greater variation in the basement. 

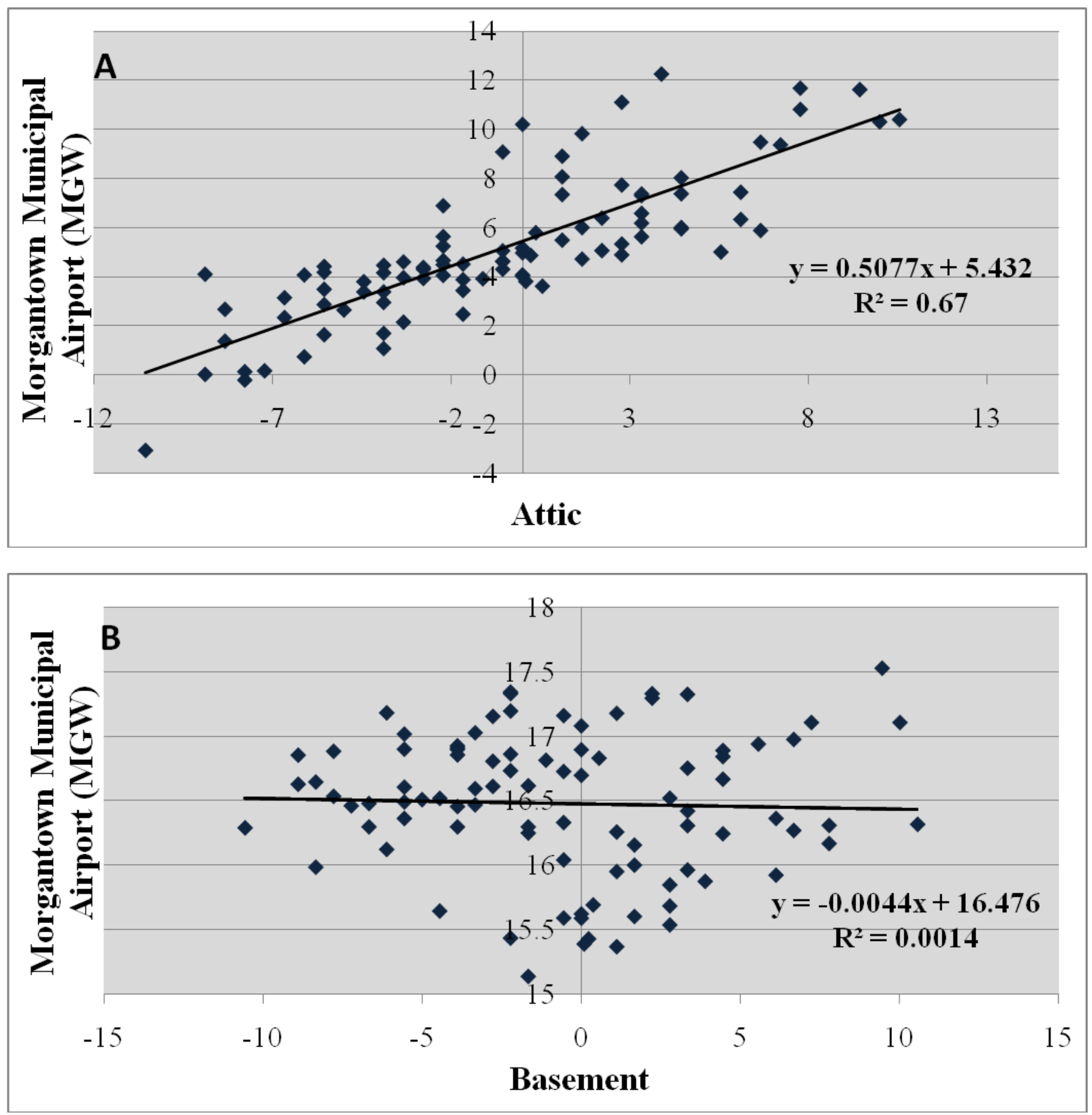

Figure 12: Comparative Analysis of Temperature. Figure 12- A) illustrates average temperature comparison of MGW and attic indicating a low correlation between outdoor temperature (MGW) and indoor (attic) temperature $\left(\mathrm{R}^{2}=0.67\right) ; 12$ - B) the comparison of basement versus airport temperatures indicate no temperature correlation between these two environments $\left(\mathrm{R}^{2}=0.0014\right) .(\mathrm{N}=90)$ 

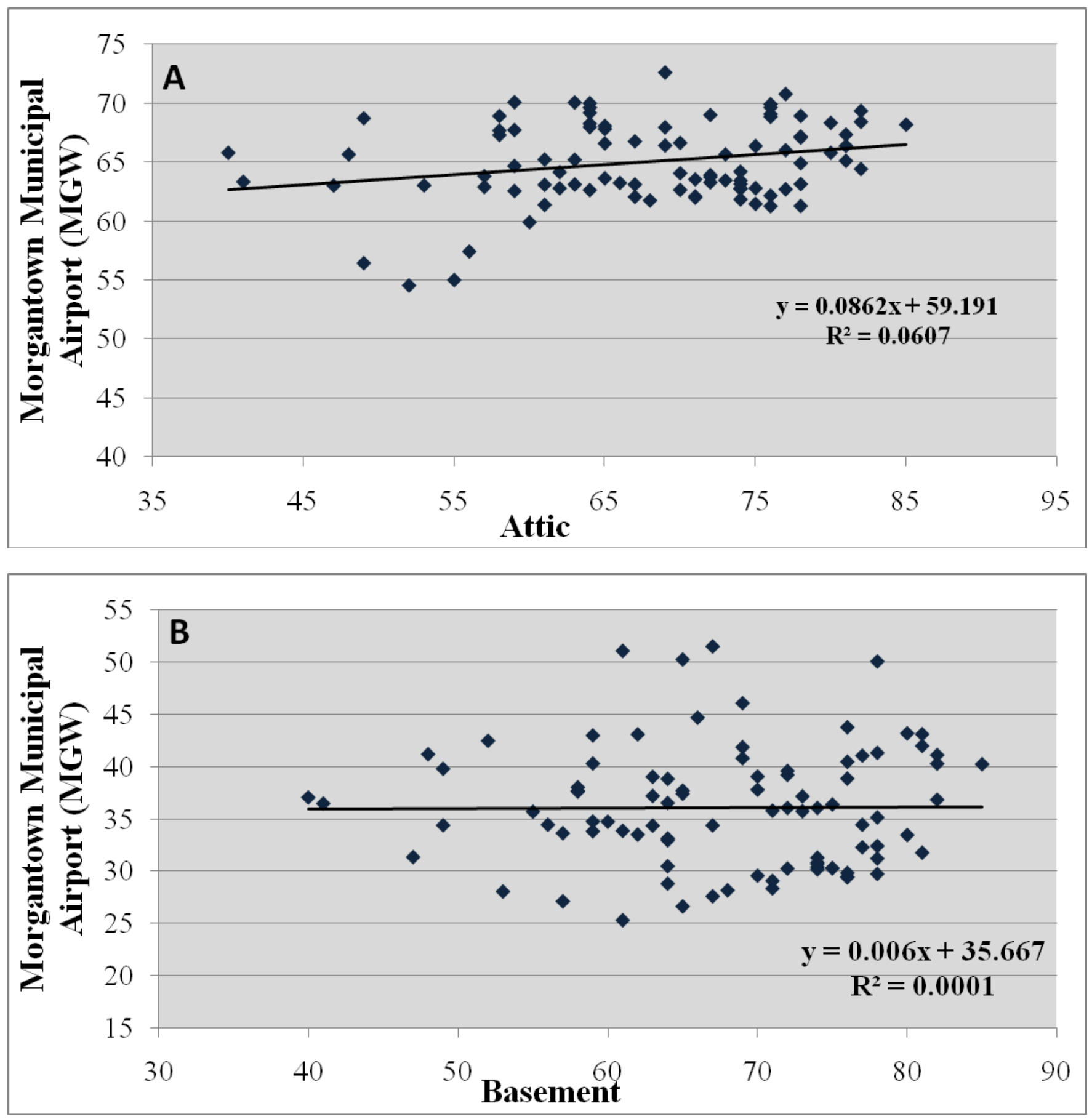

Figure 13: Average Relative Humidity (\% RH) comparisons. Figure 13-A) represents the comparison of humidity readings from the MGW versus attic; Figure 13-B) illustrates MGW versus basement relative humidity comparisons. For both comparisons, the correlation coefficient indicates no relationship between the humidity readings obtained from the MGW to either the attic, or the basement humidity data. $\left(\mathrm{R}^{2}\right.$ Attic $\left.=0.0607 ; \mathrm{R}^{2}{ }_{\text {Basement }}=0.0001\right) .(\mathrm{N}=90)$. 
Table 2: Multiplex real-time PCR Master Mix Reaction. Table displays the components and their respective volume and final concentration per amplification reaction performed in the genomic screening (GAPNT 201) as well as the two quantitative reactions ( $\beta$-actin and 18S RNAs) for each isolated RNA sample. To ensure accuracy, qPCR reactions for both $\beta$-actin and $18 \mathrm{~S}$ were performed in duplicates for each sample. Each reaction contained $20 \mu \mathrm{L}$ of master mix and $5 \mu \mathrm{L}$ of cDNA.

\begin{tabular}{|c|c|c|c|c|c|c|c|c|}
\hline \multicolumn{3}{|c|}{ Component } & \multicolumn{3}{|c|}{$\begin{array}{l}\text { Final Concentration } \\
(\mathbf{n M})\end{array}$} & \multicolumn{2}{|c|}{$\begin{array}{c}\text { Final Concentration } \\
(\mathbf{n M})\end{array}$} & \multirow{2}{*}{$\begin{array}{c}\begin{array}{c}\text { Final Concentration } \\
\text { (nM) }\end{array} \\
-\end{array}$} \\
\hline Forward Primer & \multirow{6}{*}{ 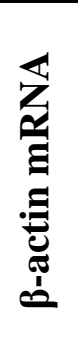 } & \multirow{3}{*}{$\sum_{0}^{\infty}$} & 900 & \multirow{6}{*}{ 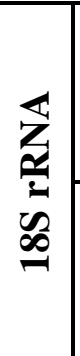 } & \multirow{3}{*}{$\underset{\infty}{\infty}$} & 1300 & \multirow{6}{*}{ 商 } & \\
\hline Reverse Primer & & & 800 & & & 1300 & & - \\
\hline FAM Probe & & & 250 & & & 250 & & - \\
\hline Forward Primer & & \multirow{3}{*}{ 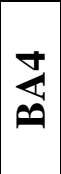 } & 50 & & \multirow{3}{*}{ : } & 60 & & 900 \\
\hline Reverse Primer & & & 50 & & & 60 & & 900 \\
\hline VIC Probe & & & 250 & & & 250 & & 250 \\
\hline \multicolumn{3}{|l|}{$\begin{array}{l}\text { TaqMan }{ }^{\circledR} \\
\text { Universal PCR } \\
\text { Master Mix }\end{array}$} & $1 X$ & & & $1 X$ & & $1 \mathrm{X}$ \\
\hline \multicolumn{2}{|l|}{$\begin{array}{l}\text { DNase/RNase- } \\
\text { Free Distilled } \\
\text { Water }\end{array}$} & & - & & & - & & - \\
\hline \multicolumn{3}{|l|}{ cDNA } & - & & & - & & - \\
\hline & & & & oren & & action $=2$ & & \\
\hline
\end{tabular}


Table 3: Accumulated Degree Days. Temperature data was obtained from both attic and basement rooms from Crime House One as well as from the Morgantown Airport. ADD was calculated from all three data sets or each collection day. To account for the exponential amplification of Real-time RT PCR, the ADD values were converted to logarithmic scale before their incorporation to the regression curve.

\begin{tabular}{|c|c|c|c|c|c|c|}
\hline \multicolumn{4}{|c|}{ ADD } & \multicolumn{3}{c|}{ LOG 10 (ADD) } \\
\hline $\begin{array}{c}\text { Exposure } \\
\text { Day }\end{array}$ & Airport & Attic & Basement & Airport & Attic & Basement \\
\hline 0 & 3.05556 & 6.344 & 17.522 & 0.485 & 0.802 & 1.244 \\
\hline 5 & 19.1667 & 38.5505 & 103.038 & 1.283 & 1.586 & 2.013 \\
\hline 10 & 36.6667 & 71.7995 & 187.365 & 1.564 & 1.856 & 2.273 \\
\hline 20 & 50.8333 & 118.524 & 354.112 & 1.706 & 2.074 & 2.549 \\
\hline 30 & 54.1667 & 139.597 & 519.099 & 1.734 & 2.145 & 2.715 \\
\hline 60 & 116.944 & 310.918 & 1014.385 & 2.068 & 2.493 & 3.006 \\
\hline 90 & 143.611 & 508.967 & 1496.0475 & 2.157 & 2.707 & 3.175 \\
\hline
\end{tabular}




\section{DISCUSSION}

Since its development and validation, Real-time PCR has been widely applied to many different biological fields for the identification and quantification of target sequences. This approach has especially been useful in gene expression studies $(46,51,52)$. This technique monitors the kinetics of product accumulation over each cycle in the PCR tube, thus decreasing the time of manipulation and processing of samples. The fundamental concept involved in Realtime PCR quantification follows the assumption that the fluorescence signal increases proportional to product accumulation. Thus, given the exponential amplification of the reaction, even small amounts of target could generate an amplification signal $(46,47,52)$.

Although its simplicity, reliability and sensitivity in target detection, real-time PCR can lead to wrong results if certain precautions are not taken (37). During sample preparation, DNA contamination of RNA samples can lead to inaccurate quantification values and thus, in our case, wrong estimation of time of deposit. Therefore, assessing for DNA contamination is an imperative step for the application of real-time RT PCR method $(36,37)$. We used a DNAspecific sequence on the GAPDH housekeeping gene to determine the levels of DNA contamination on our RNA samples prior to qPCR amplification. All amplification signals were above $35 \mathrm{C}_{\mathrm{T}}$ values, thus indicating our samples were free of DNA contamination (data not shown) (31).

Relative quantification (qPCR) relies on the comparison of the amplification signal emitted by a target and a reference segment (large and small amplicon) and the ${ }^{-\Delta \mathrm{C}}{ }_{\mathrm{T}}$ statistical method is a suitable approach to analyze data from real-time qPCR $(32,42)$. Thus, amplification efficiency of both large and small amplicons over a wide range of concentrations is 
another important step that must be performed for each amplicon pairs $(31,32)$. We used a serial dilution of a cDNA control template to determine if the amplification efficiency of both amplicons would be the same through the different dilutions. A plot of $\Delta \mathrm{C}_{\mathrm{T}}$ versus $\log \mathrm{cDNA}$ concentrations was made and the slope of the line obtained. Absolute values of the slope closer to zero indicate that both amplicons have similar amplification (32). Figures 2 and 3 illustrate the amplification efficiency of $\beta$-actin and $18 \mathrm{~S}$ multiplexes. Both slopes were very close to zero $\left(\right.$ Slope $_{\beta \text {-actin }}=0.0215 ;$ Slope $\left._{18 \mathrm{~S}}=0.0032\right)$. Therefore, the assumption of similar amplification efficiency for both, large and small amplicons, was held in both $\beta$-actin and 18S multiplex reactions; thus the $2^{-\Delta C_{T}}$ statistics for relative quantification could be used for our data analysis.

Previous studies in our laboratory demonstrated the effects of temperature and humidity on RNA degradation. Those studies, however, were performed in controlled environments with minimal levels of fluctuation $(5,10,11)$. However, it is very unlikely that at a real crime scene, the samples would be exposed to such controlled environment. Thus, the objective of this research was to analyze the environmental effects on RNA degradation of bloodstains simulating a real crime scene in order to define the limitations of the method. In addition, our aim was to determine the possible use of outdoor temperature to predict indoor temperature. Blood samples were exposed to two different rooms at Crime House One and temperature and humidity were recorded daily at 30 minute intervals.

The high temperature fluctuations in the attic could be a result of poor insulation of that room causing heat loss to the outside. The basement data, however, showed a relatively constant and higher temperature throughout the 90 days exposure (see Figure 10). On the other hand, the humidity results were the inverse of the temperature, with higher fluctuations occurring in the basement whereas the attic humidity was more constant (see Figure 11). However, in spite of 
displaying greater fluctuations, the relative humidity of the basement was always lower that $50 \%$ and would not likely be sufficient to re-hydrate the samples. Thus, it can be assumed that humidity levels encountered in the basement would not represent a major element influencing RNA degradation.

We also compared the average temperature and relative humidity between attic, basement, and Morgantown Airport (MGW) in order to determine if outdoor data could be used as a predictor of the inside environment (see Figures 12 and 13). Figure 12 shows the average daily temperature comparison of MGW versus attic and basement. It can be noticed that the attic temperature was somewhat similar to the outside readings suggesting a slight correlation between these two environments $\left(\mathrm{R}^{2}=0.67 ; \mathrm{N}=90\right)$. This association could be a result of the poor insulation on the attic allowing for diffusion of heat to the outside. The comparisons of airport versus basement, however, show no temperature correlation between these two environments $\left(\mathrm{R}^{2}=0.0014 ; \mathrm{N}=90\right)$. Moreover, the difference in temperature values recorded in each room suggests that outdoor temperature (MGW) would not be a good predictor for the inside temperatures (see Figure 12). Additionally, comparisons of the daily relative humidity data also showed no significant association of the Morgantown average \% RH with any of the indoor environments. $\left(\mathrm{R}^{2}{ }_{\mathrm{A}}=0.0607 ; \mathrm{R}^{2}{ }_{\mathrm{B}}=0.0001 ; \mathrm{N}=90\right)$ (see Figure 13).

Our results indicate that the environmental conditions had an effect on the degradation rate of both $\beta$-actin and 18S RNAs. The basement environment presented high but generally constant temperature and RNA decay occurred in a linear, predictable fashion. The $\mathrm{R}^{2}$ values of 0.9115 and 0.9036 for $\beta$-actin and $18 \mathrm{~S}$ degradation curves indicate a high correlation between ADD and amplicon ratio change (see Figures 4 and 7). Thus, suggesting the potential use of this method for estimating time of deposition. However, our results also suggest that this assay 
would only be accurate if no extreme fluctuations in temperature occur. The attic results demonstrate that the accuracy of our estimation method is extremely decreased in a highly variable environment (Figures 5 and 8). The low $\mathrm{R}^{2}$ square values indicate little to no correlation between ADD and RNA decay in the attic. Therefore, the ability of our method to accurately estimate the time of deposition is significantly decreased for samples exposed to a highly variable environment such as we observed in the attic.

Finally, our results show the importance of knowing the environmental conditions for an accurate estimation of time of deposition and how the data interpretation could be affected if this information is missing or erroneous. After the 90 day exposure period, the basement had an ADD value of 1,496.047, the attic had an ADD of 508.967, and the airport ADD was 143.111. Thus, using the ADD from one of these environments to estimate time of deposition on the other could lead to estimating the age of the sample as "older" or "younger" then it's true value.

ADD has been widely used by forensic entomologists as a means to quantify and estimate postmortem intervals (PMI). Several studies have demonstrated that environmental air temperature plays a major role, influencing maggot development, with high temperatures speeding up the rate of development $(25,28,53)$. Thus, estimation of the specimen's age is strongly associated with the amount of heat accumulated during insect growth (54).

The major goal of this pilot study was to improve the method developed by our laboratory for establishing the age of bloodstains. We were able to show that incorporating ADD into RNA degradation analysis resulted in a more reliable method for estimating time of deposition of blood samples. Additionally, the inclusion of ADD into our analysis, allowed us to account for changes in a non-controlled environment, thus demonstrating the potential use of RNA in estimating the age of biological samples left at a crime scene. This information can be 
extremely important in forensic investigations, especially within situations in which there is a known relationship between victim and suspect. In these circumstances, given the interactions between victim and suspect, it would not be uncommon to find DNA sample from either parties at the crime scene or other relevant locations. Thus, the DNA evidence could have been deposited at the crime scene previous to the crime committed; therefore, in the absence of other evidence, the location of the biological sample would not be an incriminating factor and could mislead the crime investigation. The potential use of RNA in estimating the age of biological samples can bring insight into such cases and therefore further investigation is necessary in order to determinate the full extent to which this method can be used in forensic analysis and crime scene investigations. 


\section{References}

1. Bartlett JM, Stirling D. PCR protocols: Methods in molecular biology. 2nd ed. United States of America: Human Press Inc.; 2003.

2. Butler JM. Forensic DNA typing: Biology, technology, and genetics of STR markers. 2nd ed. United States of America: Elsevier Academic Press; 2005.

3. Olsvik PA, Lie KK, Jordal AE, Nilsen TO, Hordvik I. Evaluation of potential reference genes in real-time RT-PCR studies of atlantic salmon. BMC Mol Biol. 2005 Nov 17;6:21-30.

4. Bauer M, Polzin S, Patzelt D. Quantification of RNA degradation by semi-quantitative duplex and competitive RT-PCR: A possible indicator of the age of bloodstains? Forensic Sci Int. 2003 Dec 17;138(1-3):94-103.

5. Anderson SE, Howard B, Hobbs GR, Bishop CP. A method for determining the age of a bloodstain. Forensic Sci Int. 2005 Feb 10;148(1):37-45.

6. Bauer M, Gramlich I, Polzin S, Patzelt D. Quantification of mRNA degradation as possible indicator of postmortem interval--a pilot study. Leg Med (Tokyo). 2003 Dec;5(4):220-7.

7. Mueller L. The use of DNA typing in forensic science. Accountability in Research. 1993;3(1):55-67.

8. Jobling MA, Gill P. Encoded evidence: DNA in forensic analysis Nat Rev Genet. 2004 Oct;5(10):739-51.

9. Foran DR. Relative degradation of nuclear and mitochondrial DNA: An experimental approach*. J Forensic Sci. 2006;51(4):766-70.

10. Anderson SE. RNA analysis as a method to determine the age of a biological sample. 2004.

11. Nestor KN. Use of [beta]-actin mRNA degradation to estimate bloodstain age. 2006.

12. Bauer M. RNA in forensic science. Forensic Science International: Genetics. 2007;1(1):6974.

13. Zubakov D, Hanekamp E, Kokshoorn M, van Ijcken W, Kayser M. Stable RNA markers for identification of blood and saliva stains revealed from whole genome expression analysis of time-wise degraded samples. Int J Legal Med. 2008 Mar;122(2):135-42.

14. Zubakov D, Kokshoorn M, Kloosterman A, Kayser M. New markers for old stains: Stable mRNA markers for blood and saliva identification from up to 16-year-old stains. Int J Legal Med. 2009 Jan;123(1):71-4. 
15. Zubakov D, Boersma AW, Choi Y, van Kuijk PF, Wiemer EA, Kayser M. MicroRNA markers for forensic body fluid identification obtained from microarray screening and quantitative RT-PCR confirmation. Int J Legal Med. 2010 May;124(3):217-26.

16. Jasanoff S. The eye of everyman: Witnessing DNA in the simpson trial. Soc Stud Sci. 1998;28(5-6):713-40.

17. Juusola J. Messenger RNA profiling: A prototype method to supplant conventional methods for body fluid identification. Forensic Sci Int. 2003;135(2):85-96.

18. Setzer M, Juusola J, Ballantyne J. Recovery and stability of RNA in vaginal swabs and blood, semen, and saliva stains J Forensic Sci. 2008 Mar;53(2):296-305.

19. Lee J, Hever A, Willhite D, Zlotnik A, Hevezi P. Effects of RNA degradation on gene expression analysis of human postmortem tissues. FASEB J. 2005 Aug;19(10):1356-8.

20. Wong ML, Medrano JF. Real-time PCR for mRNA quantitation BioTechniques. 2005 Jul;39(1):75-85.

21. Smith TL. Investigating the potential of RNA to be used in forensic casework analysis. 2010.

22. Currie LA. The remarkable metrological history of radiocarbon dating [II]. J Res Natl Inst Stand Technol. 2004;109(2):185-217.

23. Megyesi MS, Nawrocki SP, Haskell NH. Using accumulated degree-days to estimate the postmortem interval from decomposed human remains. J Forensic Sci. 2005;50(3):1-9.

24. Larkin B, Iaschi S, Dadour I, Tay GK. Using accumulated degree-days to estimate postmortem interval from the DNA yield of porcine skeletal muscle. Forensic Sci Med Pathol. 2009 Jun;6(2):83-92.

25. Niederegger S, Pastuschek J, Mall G. Preliminary studies of the influence of fluctuating temperatures on the development of various forensically relevant flies. Forensic Sci Int. 2010 Apr 9;199(1):72-78.

26. Viator RP, Nuti RC, Edmisten KL, Wells R. Predicting cotton boll maturation period using degree days and other climatic factors. Agronomy journal. 2005;97(2):494-499.

27. Baskerville GL, Emin P. Rapid estimation of heat accumulation from maximum and minimum temperatures. Ecology. 1969;50(3):514-517.

28. Vass AA. The elusive universal post-mortem interval formula. Forensic Sci Int. 2010;In Press, Corrected Proof.

29. Onset Computer Corporation. HOBOware ${ }^{\circledR}$ lite: Software for $\mathrm{HOBO} \circledast$ data loggers \& devices - user's guide. 2003. 
30. Morgantown airport (MGW) weather history: December 8, 2009 through march 8, 2010. [homepage on the Internet].; 2010. Available from: http://www.wunderground.com.

31. Applied Biosystems. Application note - amplification efficiency of TaqMan ${ }^{\circledR}$ gene expression assays. . 2006. Available from: http://www3.appliedbiosystems.com/cms/groups/mcb_marketing/documents/generaldoc uments/cms_040377.pdf.

32. Livak KJ, Schmittgen TD. Analysis of relative gene expression data using real-time quantitative PCR and the 2(-delta delta C(T)) method. Methods. 2001 Dec;25(4):402408.

33. Bustin SA. Quantification of mRNA using real-time reverse transcription PCR (RT-PCR): Trends and problems. J Mol Endocrinol. 2002 Aug;29(1):23-39.

34. Molecular Research Center. TRI Reagent®BD: RNA, DNA, protein isolation reagent. Manufacturer's protocol. 1995.

35. Applied Biosystems. TaqMan® gold RT-PCR kit: Protocol. 2006. Available from: http://www3.appliedbiosystems.com/cms/groups/mcb_support/documents/generaldocum ents/cms_040930.pdf.

36. Winer J, Jung CK, Shackel I, Williams PM. Development and validation of real-time quantitative reverse transcriptase-polymerase chain reaction for monitoring gene expression in cardiac myocytes in vitro. Anal Biochem. 1999 May 15;270(1):41-49.

37. Udvardi MK, Czechowski T, Scheible W-. Eleven golden rules of quantitative RT-PCR. The Plant Cell Online. 2008;20(7):1736-1737.

38. Freeman WM, Walker SJ, Vrana KE. Quantitative RT-PCR: Pitfalls and potential. BioTechniques. 1999 Jan;26(1):112,22,124-25.

39. Barber RD, Harmer DW, Coleman RA, Clark BJ. GAPDH as a housekeeping gene: Analysis of GAPDH mRNA expression in a panel of 72 human tissues. Physiol Genomics. 2005 May 11;21(3):389-395.

40. Tarze A, Deniaud A, Le Bras M, Maillier E, Molle D, Larochette N, et al. GAPDH, a novel regulator of the pro-apoptotic mitochondrial membrane permeabilization. Oncogene. 2007 Apr 19;26(18):2606-2620.

41. Applied Biosystems. TaqMan® universal PCR master mix protocol. . 2002. Available from: http://www3.appliedbiosystems.com/cms/groups/mcb_support/documents/generaldocum ents/cms 042996.pdf. 
42. Peirson SN, Butler JN, Foster RG. Experimental validation of novel and conventional approaches to quantitative real-time PCR data analysis. Nucleic Acids Res. 2003 Jul 15;31(14):e73.

43. Skern R, Frost P, Nilsen F. Relative transcript quantification by quantitative PCR: Roughly right or precisely wrong? BMC Mol Biol. 2005 Apr 26;6(1):10.

44. Liu W, Saint DA. A new quantitative method of real time reverse transcription polymerase chain reaction assay based on simulation of polymerase chain reaction kinetics. Anal Biochem. 2002 Mar 1;302(1):52-59.

45. Holland PM, Abramson RD, Watson R, Gelfand DH. Detection of specific polymerase chain reaction product by utilizing the 5'----3' exonuclease activity of thermus aquaticus DNA polymerase. Proc Natl Acad Sci U S A. 1991 Aug 15;88(16):7276-7280.

46. Edwards K, Logan J, Saunders N. Real-time PCR: An essential guide. Edwards K, Logan J, Saunders N, editors. Norfolk, United Kingdom: Horizon Bioscience; 2004.

47. Applied Biosystems. Application note - real-time PCR: Understanding CT. 2008. Available from:

http://www3.appliedbiosystems.com/cms/groups/mcb_marketing/documents/generaldoc uments/cms_053906.pdf.

48. Applied Biosystems.User Bulletin 2: ABI prims 7700 sequencer detection system. 1997.

Available from:

http://www3.appliedbiosystems.com/cms/groups/mcb_support/documents/generaldocum ents/cms_040980.pdf.

49. Applied Biosystems. Relative quantification using comparative CT: Getting started guide. 2006. Available from:

http://www3.appliedbiosystems.com/cms/groups/mcb_support/documents/generaldocum ents/cms_041435.pdf

50. Koczan D, Guthke R, Thiesen HJ, Ibrahim SM, Kundt G, Krentz H, et al. Gene expression profiling of peripheral blood mononuclear leukocytes from psoriasis patients identifies new immune regulatory molecules. Eur J Dermatol. 2005 Jul-Aug;15(4):251-257.

51. Pfaffl MW. A new mathematical model for relative quantification in real-time RT-PCR. Nucleic Acids Res. 2001 May 1;29(9):e45-50.

52. Liu W, Saint DA. Validation of a quantitative method for real time PCR kinetics. Biochem Biophys Res Commun. 2002 Jun 7;294(2):347-53.

53. Dabbs GR. Caution! all data are not created equal: The hazards of using national weather service data for calculating accumulated degree days. Forensic Sci Int. 2010 Oct 10;202(1-3):e49-52. 
54. Amendt J, Campobasso CP, Gaudry E, Reiter C, LeBlanc HN, Hall MJ, et al. Best practice in forensic entomology--standards and guidelines. Int J Legal Med. 2007 Mar;121(2):90104. 


\section{APPENDIX I}

6.1 Daily Temperature Readings - December, 2009 - March, 2010

\begin{tabular}{|c|c|c|c|c|c|c|c|c|c|c|}
\hline \multirow[b]{3}{*}{$\begin{array}{c}\text { Exposure } \\
\text { Day }\end{array}$} & \multicolumn{9}{|c|}{ Temperature ${ }^{\circ} \mathrm{C}$} & \\
\hline & \multicolumn{3}{|c|}{ Airport } & \multicolumn{3}{|c|}{ Attic } & \multicolumn{3}{|c|}{ Basement } & \\
\hline & Avg & Max & Min & Avg & Max & Min & Avg & $\operatorname{Max}$ & Min & \\
\hline 0 & 3.33 & 5.00 & 1.11 & 6.18 & 8.48 & 4.21 & 17.32 & 17.86 & 17.19 & \\
\hline 1 & 9.44 & 17.22 & 1.67 & 11.63 & 17.19 & 7.68 & 17.53 & 18.43 & 16.71 & \\
\hline 2 & -2.22 & 1.67 & -6.67 & 6.89 & 9.67 & 1.44 & 17.34 & 17.67 & 17.19 & \\
\hline 3 & -3.89 & 0.00 & -7.78 & 1.68 & 10.16 & -3.79 & 16.90 & 17.19 & 16.71 & \\
\hline 4 & 0.00 & 6.67 & -7.22 & 4.02 & 14.80 & -3.43 & 16.70 & 16.90 & 16.43 & \\
\hline 5 & 6.67 & 11.11 & 2.22 & 5.88 & 9.47 & 1.22 & 16.97 & 17.19 & 16.62 & \\
\hline 6 & 10.00 & 15.00 & 5.00 & 10.31 & 15.00 & 7.58 & 17.11 & 17.19 & 17.00 & \\
\hline 7 & 7.22 & 13.33 & 0.56 & 9.37 & 11.43 & 5.04 & 17.11 & 17.19 & 17.00 & \\
\hline 8 & -2.22 & 0.56 & -5.00 & 4.66 & 12.69 & 0.34 & 16.73 & 17.00 & 16.43 & \\
\hline 9 & -3.33 & 1.11 & -8.33 & 2.14 & 10.36 & -3.67 & 16.59 & 16.81 & 16.43 & ర్తి \\
\hline 10 & 0.56 & 5.56 & -4.44 & 3.61 & 8.28 & -0.55 & 16.83 & 17.00 & 16.62 & $\because$ \\
\hline 11 & -2.22 & -0.56 & -3.89 & 4.05 & 5.14 & 3.58 & 16.86 & 16.90 & 16.81 & है \\
\hline 12 & -2.78 & -1.67 & -4.44 & 3.93 & 4.62 & 3.47 & 16.61 & 16.81 & 16.33 & 边 \\
\hline 13 & -1.11 & 0.56 & -3.33 & 3.91 & 4.10 & 3.68 & 16.81 & 16.90 & 16.62 & \\
\hline 14 & 0.00 & 1.11 & -1.11 & 4.07 & 4.31 & 3.89 & 16.90 & 16.90 & 16.81 & \\
\hline 15 & -3.33 & 0.56 & -7.22 & 3.95 & 4.62 & 2.62 & 16.47 & 16.81 & 16.14 & \\
\hline 16 & -1.67 & 6.67 & -10.00 & 2.46 & 5.45 & 0.01 & 16.25 & 16.43 & 15.95 & \\
\hline 17 & 5.56 & 8.33 & 2.78 & 5.00 & 6.17 & 3.89 & 16.94 & 17.19 & 16.43 & \\
\hline 18 & 4.44 & 8.89 & -0.56 & 7.38 & 11.04 & 2.84 & 16.89 & 17.09 & 16.71 & \\
\hline 19 & 4.44 & 7.78 & 1.11 & 6.00 & 14.61 & 0.12 & 16.67 & 16.90 & 16.43 & \\
\hline 20 & -1.67 & 1.67 & -5.56 & 3.43 & 7.18 & 2.09 & 16.62 & 16.81 & 16.52 & \\
\hline 21 & -6.67 & -2.22 & -11.11 & 2.33 & 5.96 & -1.80 & 16.48 & 16.81 & 16.14 & \\
\hline 22 & -3.89 & 2.78 & -11.11 & 1.07 & 6.06 & -3.20 & 16.46 & 16.62 & 16.24 & \\
\hline 23 & 3.33 & 5.56 & 1.11 & 5.62 & 7.38 & 4.10 & 16.75 & 16.81 & 16.62 & \\
\hline 24 & -0.56 & 3.89 & -5.56 & 4.63 & 6.57 & 1.33 & 16.73 & 16.81 & 16.62 & \\
\hline
\end{tabular}




\begin{tabular}{|c|c|c|c|c|c|c|c|c|c|c|}
\hline & \multicolumn{3}{|c|}{ Airport } & \multicolumn{3}{|c|}{ Attic } & \multicolumn{3}{|c|}{ Basement } & \\
\hline $\begin{array}{c}\text { Exposure } \\
\text { Day }\end{array}$ & Avg & $\operatorname{Max}$ & Min & Avg & Max & Min & Avg & $\operatorname{Max}$ & Min & \\
\hline 24 & -0.56 & 3.89 & -5.56 & 4.63 & 6.57 & 1.33 & 16.73 & 16.81 & 16.62 & \\
\hline 25 & -7.78 & -5.56 & -10.00 & -0.22 & 1.22 & -2.73 & 16.53 & 16.71 & 16.43 & \\
\hline 26 & -10.56 & -7.78 & -13.33 & -3.09 & 0.45 & -6.25 & 16.29 & 16.33 & 16.14 & \\
\hline 27 & -7.22 & -5.56 & -8.89 & 0.16 & 2.84 & -2.26 & 16.46 & 16.52 & 16.33 & \\
\hline 28 & -5.56 & -5.00 & -6.11 & 1.63 & 3.05 & 0.67 & 16.49 & 16.52 & 16.43 & \\
\hline 29 & -5.00 & -3.89 & -6.11 & 2.64 & 3.37 & 1.44 & 16.51 & 16.52 & 16.43 & \\
\hline 30 & -4.44 & -3.33 & -5.56 & 3.37 & 3.79 & 2.84 & 16.52 & 16.52 & 16.43 & \\
\hline 31 & -6.67 & -2.78 & -10.56 & 3.14 & 3.58 & 2.62 & 16.30 & 16.52 & 16.14 & \\
\hline 32 & -5.56 & -3.33 & -8.33 & 2.86 & 3.47 & 2.30 & 16.36 & 16.52 & 16.24 & \\
\hline 33 & -8.33 & -5.00 & -12.22 & 2.66 & 3.58 & 1.00 & 15.99 & 16.24 & 15.76 & \\
\hline 34 & -6.11 & -2.22 & -10.56 & 0.73 & 2.62 & -1.57 & 16.12 & 16.33 & 15.95 & \\
\hline 35 & -3.89 & -2.78 & -5.56 & 2.94 & 3.79 & 2.09 & 16.30 & 16.52 & 16.05 & \\
\hline 36 & -1.67 & 0.00 & -3.89 & 3.88 & 7.18 & 2.30 & 16.30 & 16.52 & 15.95 & gे \\
\hline 37 & 1.67 & 7.22 & -3.89 & 4.71 & 12.11 & 0.12 & 16.00 & 16.24 & 15.76 & 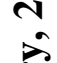 \\
\hline 38 & 4.44 & 5.56 & 2.78 & 5.95 & 7.78 & 4.00 & 16.24 & 16.33 & 15.95 & $\stackrel{5}{=}$ \\
\hline 39 & 6.67 & 11.11 & 2.22 & 9.48 & 16.81 & 5.86 & 16.27 & 16.43 & 16.05 & ప \\
\hline 40 & 6.11 & 8.89 & 2.78 & 7.44 & 9.08 & 6.06 & 16.36 & 16.52 & 16.14 & \\
\hline 41 & 3.33 & 6.11 & 0.56 & 7.31 & 9.87 & 3.89 & 16.42 & 16.52 & 16.33 & \\
\hline 42 & 2.78 & 4.44 & 0.56 & 4.89 & 6.78 & 2.62 & 16.52 & 16.71 & 16.33 & \\
\hline 43 & 1.11 & 3.89 & -1.67 & 5.49 & 12.01 & 1.33 & 16.26 & 16.52 & 16.05 & \\
\hline 44 & 3.33 & 7.22 & -1.11 & 6.58 & 14.71 & 0.56 & 16.31 & 16.71 & 16.05 & \\
\hline 45 & 4.44 & 6.11 & 2.22 & 8.03 & 10.65 & 6.27 & 16.84 & 17.00 & 16.52 & \\
\hline 46 & 7.78 & 11.11 & 3.89 & 11.68 & 19.47 & 7.38 & 16.17 & 16.43 & 15.86 & \\
\hline 47 & 10.56 & 14.44 & 6.11 & 10.41 & 12.59 & 7.88 & 16.32 & 16.43 & 16.05 & \\
\hline 48 & 7.78 & 13.89 & 1.11 & 10.82 & 12.79 & 5.76 & 16.31 & 16.43 & 16.14 & \\
\hline 49 & -0.56 & 1.67 & -3.33 & 4.30 & 5.55 & 2.73 & 16.33 & 17.00 & 15.57 & \\
\hline 50 & -0.56 & 1.11 & -2.78 & 5.05 & 11.53 & 1.98 & 17.16 & 17.28 & 17.00 & \\
\hline 51 & -2.22 & 3.33 & -8.33 & 5.63 & 13.17 & 0.01 & 17.19 & 17.57 & 16.81 & \\
\hline 52 & -8.89 & -6.67 & -11.11 & 0.01 & 6.17 & -4.76 & 16.85 & 17.00 & 16.81 & \\
\hline 53 & -7.78 & -6.11 & -10.00 & 0.12 & 2.30 & -1.57 & 16.88 & 17.00 & 16.81 & \\
\hline 54 & -8.33 & -1.67 & -15.56 & 1.37 & 8.98 & -3.31 & 16.65 & 16.81 & 16.43 & \\
\hline
\end{tabular}




\begin{tabular}{|c|c|c|c|c|c|c|c|c|c|c|}
\hline & \multicolumn{3}{|c|}{ Airport } & \multicolumn{3}{|c|}{ Attic } & \multicolumn{3}{|c|}{ Basement } & \\
\hline $\begin{array}{c}\text { Exposure } \\
\text { Day }\end{array}$ & Avg & Max & Min & Avg & Max & Min & Avg & $\operatorname{Max}$ & Min & \\
\hline 55 & -3.89 & 1.67 & -9.44 & 3.38 & 11.82 & -2.84 & 16.86 & 16.90 & 16.81 & \\
\hline 56 & 0.00 & 4.44 & -4.44 & 4.97 & 10.26 & 0.78 & 17.08 & 17.19 & 16.81 & \\
\hline 57 & 2.22 & 3.33 & 0.56 & 6.39 & 8.78 & 5.24 & 17.33 & 17.38 & 17.19 & \\
\hline 58 & 1.11 & 3.33 & -1.11 & 7.34 & 14.42 & 3.37 & 17.18 & 17.28 & 17.00 & \\
\hline 59 & 2.22 & 3.89 & 0.00 & 5.06 & 6.17 & 4.62 & 17.29 & 17.48 & 17.09 & \\
\hline 60 & -4.44 & 0.56 & -10.00 & 3.79 & 4.62 & 3.26 & 15.65 & 17.38 & 13.75 & \\
\hline 61 & -8.89 & -6.11 & -11.67 & 4.09 & 4.62 & 3.68 & 16.63 & 16.71 & 16.52 & \\
\hline 62 & -5.56 & -2.22 & -8.89 & 4.41 & 5.14 & 3.89 & 16.61 & 16.90 & 16.14 & \\
\hline 63 & -2.78 & 3.89 & -9.44 & 4.30 & 4.62 & 3.89 & 16.81 & 17.09 & 16.43 & \\
\hline 64 & -3.89 & 1.67 & -10.00 & 4.16 & 4.52 & 3.79 & 16.93 & 17.19 & 16.71 & \\
\hline 65 & -2.78 & -1.67 & -3.89 & 4.37 & 4.62 & 4.10 & 17.15 & 17.19 & 17.09 & $\Theta$ \\
\hline 66 & -3.33 & -1.11 & -5.56 & 4.60 & 5.14 & 4.21 & 17.03 & 17.19 & 16.81 & ন \\
\hline 67 & -3.89 & -2.22 & -5.56 & 4.46 & 4.83 & 4.21 & 16.91 & 17.00 & 16.90 & है \\
\hline 68 & -5.56 & -2.22 & -9.44 & 4.17 & 4.31 & 4.00 & 17.02 & 17.09 & 17.00 & \\
\hline 69 & -5.56 & 0.56 & -12.22 & 3.48 & 4.10 & 2.62 & 16.90 & 17.09 & 16.71 & 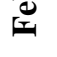 \\
\hline 70 & -6.11 & -2.78 & -10.00 & 4.07 & 4.52 & 3.68 & 17.18 & 18.14 & 16.81 & \\
\hline 71 & -2.22 & -1.11 & -3.33 & 4.48 & 5.04 & 4.10 & 17.33 & 18.14 & 17.19 & \\
\hline 72 & -0.56 & 0.56 & -1.67 & 4.61 & 5.24 & 4.31 & 16.04 & 17.38 & 11.33 & \\
\hline 73 & 0.00 & 3.33 & -3.33 & 5.16 & 5.86 & 4.73 & 15.59 & 15.76 & 15.28 & \\
\hline 74 & -1.67 & 5.00 & -8.89 & 4.51 & 6.06 & 2.73 & 15.14 & 15.47 & 14.71 & \\
\hline 75 & 2.78 & 6.67 & -1.67 & 5.33 & 6.78 & 4.00 & 15.54 & 15.86 & 15.19 & \\
\hline 76 & 6.11 & 8.33 & 3.33 & 6.33 & 7.68 & 4.83 & 15.92 & 16.14 & 15.66 & \\
\hline 77 & 3.33 & 5.00 & 1.11 & 7.37 & 9.08 & 6.17 & 15.96 & 16.05 & 15.86 & \\
\hline 78 & 1.67 & 4.44 & -1.67 & 9.83 & 19.76 & 3.58 & 15.60 & 15.86 & 15.28 & \\
\hline 79 & -2.22 & 0.00 & -5.00 & 5.24 & 7.78 & 2.84 & 15.44 & 15.47 & 15.28 & \\
\hline 80 & 0.09 & -1.11 & -5.00 & 3.80 & 4.83 & 2.52 & 15.39 & 15.47 & 15.19 & \\
\hline 81 & 0.23 & 1.11 & -2.78 & 4.86 & 5.35 & 4.52 & 15.43 & 15.47 & 15.38 & \\
\hline 82 & 0.37 & 3.89 & -1.11 & 5.79 & 7.88 & 4.73 & 15.69 & 15.86 & 15.47 & \\
\hline 83 & 2.78 & 3.89 & 1.11 & 7.73 & 11.53 & 5.14 & 15.85 & 16.05 & 15.76 & \\
\hline 84 & 1.11 & 3.33 & -1.11 & 8.07 & 13.27 & 4.31 & 15.95 & 16.05 & 15.86 & \\
\hline 85 & 1.67 & 2.78 & 0.00 & 6.00 & 7.48 & 4.93 & 16.16 & 16.24 & 15.95 & 을 \\
\hline 86 & 1.11 & 5.56 & -3.33 & 8.91 & 21.76 & 0.89 & 15.37 & 16.14 & 12.50 & సิ \\
\hline 87 & -0.56 & 6.11 & -7.22 & 9.08 & 23.00 & -1.00 & 15.59 & 15.76 & 15.28 & 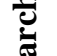 \\
\hline 88 & 0.00 & 6.67 & -6.67 & 10.21 & 24.84 & -0.33 & 15.62 & 15.86 & 15.38 & $\sum$ \\
\hline 89 & 2.78 & 10.56 & -5.56 & 11.11 & 26.49 & 0.01 & 15.69 & 16.05 & 15.47 & \\
\hline 90 & 3.89 & 12.22 & -4.44 & 12.26 & 27.76 & 1.11 & 15.88 & 15.95 & 15.57 & \\
\hline
\end{tabular}


6.2 Daily Relative Humidity Readings - December, 2009 - March, 2010

\begin{tabular}{|c|c|c|c|c|c|c|c|c|c|c|}
\hline \multicolumn{10}{|c|}{ Relative Humidity (\%) } & \\
\hline \multirow[b]{2}{*}{ Exposure Day } & \multicolumn{3}{|c|}{ Airport } & \multicolumn{3}{|c|}{ Attic } & \multicolumn{3}{|c|}{ Basement } & \multirow{27}{*}{ 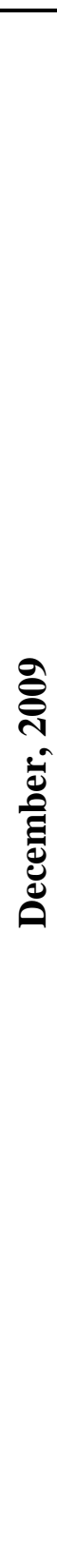 } \\
\hline & Avg & Max & Min & Avg & $\operatorname{Max}$ & Min & Avg & Max & Min & \\
\hline $\mathbf{0}$ & 69 & 82 & 55 & 72.6 & 74.6 & 69.5 & 46.1 & 48.4 & 44.5 & \\
\hline 1 & 61 & 83 & 38 & 65.2 & 76.9 & 53.2 & 51.1 & 58.3 & 48.2 & \\
\hline 2 & 52 & 63 & 40 & 54.6 & 59.4 & 50.6 & 42.5 & 48.3 & 38.8 & \\
\hline 3 & 41 & 54 & 28 & 63.4 & 70.0 & 58.1 & 36.5 & 38.3 & 35.6 & \\
\hline 4 & 40 & 62 & 18 & 65.8 & 78.1 & 60.1 & 37.1 & 38.6 & 36.1 & \\
\hline 5 & 59 & 93 & 24 & 67.7 & 69.4 & 65.1 & 43.0 & 48.8 & 38.6 & \\
\hline 6 & 65 & 89 & 40 & 68.1 & 69.7 & 66.1 & 50.3 & 52.7 & 48.8 & \\
\hline 7 & 67 & 79 & 54 & 66.8 & 68.3 & 64.7 & 51.5 & 53.6 & 46.9 & \\
\hline 8 & 48 & 60 & 36 & 65.7 & 73.6 & 60.1 & 41.2 & 46.4 & 38.7 & \\
\hline 9 & 58 & 80 & 36 & 68.9 & 78.6 & 63.5 & 37.7 & 38.6 & 37.2 & \\
\hline 10 & 64 & 85 & 43 & 69.2 & 72.5 & 67.2 & 38.8 & 40.5 & 37.9 & \\
\hline 11 & 85 & 92 & 78 & 68.2 & 68.7 & 67.3 & 40.2 & 40.8 & 39.4 & \\
\hline 12 & 76 & 88 & 63 & 69.1 & 70.5 & 68.3 & 38.9 & 39.5 & 38.3 & \\
\hline 13 & 82 & 92 & 72 & 69.4 & 70.6 & 68.6 & 40.3 & 41.8 & 39.1 & \\
\hline 14 & 77 & 85 & 69 & 70.8 & 71.4 & 70.3 & 41.1 & 41.8 & 40.6 & \\
\hline 15 & 63 & 84 & 41 & 70.1 & 71.2 & 69.0 & 39.0 & 40.8 & 37.4 & \\
\hline 16 & 64 & 88 & 39 & 70.0 & 71.2 & 68.9 & 36.5 & 38.2 & 34.6 & \\
\hline 17 & 59 & 79 & 38 & 70.1 & 72.1 & 68.4 & 40.3 & 43.1 & 38.0 & \\
\hline 18 & 76 & 92 & 59 & 69.9 & 72.8 & 66.2 & 43.8 & 45.6 & 42.5 & \\
\hline 19 & 49 & 64 & 34 & 68.7 & 79.6 & 61.1 & 39.8 & 42.4 & 37.8 & \\
\hline 20 & 70 & 81 & 58 & 64.1 & 65.4 & 62.5 & 37.8 & 41.2 & 35.7 & \\
\hline 21 & 63 & 80 & 46 & 63.1 & 65.5 & 59.1 & 34.4 & 36.7 & 33.5 & \\
\hline 22 & 64 & 84 & 44 & 68.3 & 70.9 & 65.6 & 33.1 & 35.3 & 31.9 & \\
\hline 23 & 72 & 96 & 48 & 69.0 & 69.9 & 67.7 & 39.6 & 43.0 & 35.4 & \\
\hline 24 & 76 & 89 & 62 & 68.9 & 70.0 & 67.6 & 40.5 & 43.0 & 36.4 & \\
\hline
\end{tabular}




\begin{tabular}{|c|c|c|c|c|c|c|c|c|c|c|}
\hline & \multicolumn{3}{|c|}{ Airport } & \multicolumn{3}{|c|}{ Attic } & \multicolumn{3}{|c|}{ Basement } & \\
\hline $\begin{array}{c}\text { Exposure } \\
\text { Day }\end{array}$ & Avg & $\operatorname{Max}$ & Min & Avg & Max & Min & Avg & Max & Min & \\
\hline 25 & 64 & 77 & 51 & 68.0 & 69.2 & 66.1 & 33.0 & 36.3 & 30.7 & \\
\hline 26 & 64 & 73 & 54 & 69.6 & 72.1 & 67.9 & 28.8 & 30.6 & 27.8 & \\
\hline 27 & 76 & 84 & 67 & 69.7 & 70.6 & 68.7 & 29.8 & 31.2 & 29.0 & \\
\hline 28 & 78 & 84 & 71 & 68.9 & 69.9 & 67.2 & 31.2 & 31.5 & 30.9 & \\
\hline 29 & 81 & 84 & 77 & 67.4 & 67.6 & 67.0 & 31.8 & 32.6 & 31.1 & \\
\hline 30 & 78 & 88 & 68 & 67.1 & 67.5 & 66.0 & 32.4 & 33.2 & 31.9 & \\
\hline 31 & 74 & 81 & 67 & 63.2 & 67.4 & 60.8 & 30.2 & 33.4 & 28.7 & \\
\hline 32 & 70 & 81 & 59 & 62.7 & 64.0 & 61.3 & 29.6 & 30.3 & 28.7 & \\
\hline 33 & 71 & 84 & 57 & 62.1 & 63.0 & 61.0 & 28.4 & 29.7 & 27.5 & \\
\hline 34 & 67 & 88 & 46 & 63.1 & 63.9 & 62.5 & 27.6 & 29.7 & 26.6 & \\
\hline 35 & 74 & 84 & 63 & 64.2 & 64.6 & 63.9 & 30.4 & 31.2 & 29.9 & \\
\hline 36 & 64 & 74 & 54 & 62.7 & 64.4 & 58.2 & 30.5 & 30.9 & 29.6 & 으 \\
\hline 37 & 47 & 63 & 31 & 63.0 & 65.6 & 58.8 & 31.4 & 33.0 & 30.4 & $\overline{\mathrm{N}}$ \\
\hline 38 & 59 & 79 & 38 & 62.6 & 63.1 & 61.8 & 34.8 & 37.5 & 32.9 & $\vec{z}$ \\
\hline 39 & 72 & 85 & 59 & 63.9 & 69.9 & 61.5 & 39.2 & 41.1 & 37.6 & 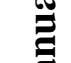 \\
\hline 40 & 81 & 92 & 70 & 65.1 & 67.3 & 63.1 & 42.0 & 43.8 & 40.3 & $\stackrel{\bar{\sigma}}{\leftrightarrows}$ \\
\hline 41 & 81 & 92 & 70 & 66.4 & 67.6 & 64.8 & 43.1 & 43.9 & 41.1 & \\
\hline 42 & 82 & 89 & 75 & 68.4 & 69.5 & 65.9 & 41.1 & 41.9 & 40.1 & \\
\hline 43 & 65 & 78 & 52 & 67.8 & 79.8 & 63.2 & 37.7 & 39.9 & 36.8 & \\
\hline 44 & 63 & 76 & 49 & 65.2 & 73.7 & 60.5 & 37.2 & 40.0 & 35.4 & \\
\hline 45 & 78 & 85 & 70 & 64.9 & 66.4 & 63.4 & 41.3 & 42.7 & 39.8 & \\
\hline 46 & 62 & 79 & 44 & 64.2 & 72.4 & 59.6 & 43.1 & 43.9 & 42.2 & \\
\hline 47 & 66 & 83 & 49 & 63.3 & 67.6 & 60.3 & 44.7 & 50.0 & 41.5 & \\
\hline 48 & 78 & 93 & 62 & 67.2 & 69.6 & 64.6 & 50.1 & 52.8 & 43.9 & \\
\hline 49 & 69 & 85 & 53 & 66.4 & 67.9 & 64.7 & 40.8 & 43.8 & 36.9 & \\
\hline 50 & 59 & 68 & 49 & 64.7 & 67.9 & 59.1 & 33.8 & 36.5 & 32.9 & \\
\hline 51 & 61 & 89 & 33 & 61.4 & 68.9 & 52.7 & 33.9 & 36.4 & 31.0 & \\
\hline 52 & 53 & 61 & 45 & 63.1 & 68.5 & 57.9 & 28.1 & 30.9 & 26.7 & \\
\hline 53 & 65 & 80 & 49 & 63.7 & 65.0 & 61.7 & 26.6 & 27.6 & 25.8 & \\
\hline 54 & 61 & 87 & 35 & 63.1 & 70.8 & 56.8 & 25.3 & 26.3 & 24.5 & \\
\hline
\end{tabular}




\begin{tabular}{|c|c|c|c|c|c|c|c|c|c|c|}
\hline & \multicolumn{3}{|c|}{ Airport } & \multicolumn{3}{|c|}{ Attic } & \multicolumn{3}{|c|}{ Basement } & \\
\hline $\begin{array}{c}\text { Exposure } \\
\text { Day }\end{array}$ & Avg & Max & Min & Avg & $\operatorname{Max}$ & Min & Avg & $\operatorname{Max}$ & Min & \\
\hline 55 & 57 & 73 & 41 & 62.9 & 70.4 & 58.9 & 27.1 & 28.9 & 26.1 & \\
\hline 56 & 74 & 96 & 52 & 62.8 & 65.6 & 60.4 & 30.8 & 34.6 & 28.9 & \\
\hline 57 & 78 & 92 & 64 & 63.2 & 64.4 & 62.1 & 35.1 & 35.6 & 34.6 & \\
\hline 58 & 62 & 72 & 52 & 62.8 & 69.2 & 58.4 & 33.5 & 34.5 & 33.0 & \\
\hline 59 & 67 & 89 & 44 & 62.1 & 64.8 & 59.7 & 34.4 & 36.1 & 32.6 & \\
\hline 60 & 74 & 85 & 63 & 63.5 & 64.9 & 62.2 & 36.1 & 37.9 & 31.1 & \\
\hline 61 & 76 & 84 & 67 & 62.2 & 63.3 & 61.5 & 29.4 & 30.9 & 28.8 & \\
\hline 62 & 71 & 84 & 57 & 62.0 & 63.8 & 60.9 & 29.1 & 29.9 & 28.6 & \\
\hline 63 & 74 & 85 & 63 & 61.9 & 64.5 & 59.8 & 31.3 & 35.7 & 28.6 & \\
\hline 64 & 75 & 89 & 61 & 61.5 & 64.9 & 59.1 & 30.3 & 35.7 & 27.2 & \\
\hline 65 & 75 & 81 & 69 & 62.8 & 63.8 & 61.6 & 30.3 & 31.1 & 29.5 & \\
\hline 66 & 72 & 81 & 63 & 63.3 & 64.0 & 62.2 & 30.3 & 31.2 & 29.1 & $\overrightarrow{8}$ \\
\hline 67 & 74 & 84 & 63 & 62.8 & 63.2 & 62.3 & 30.7 & 31.4 & 30.1 & \\
\hline 68 & 76 & 84 & 68 & 61.3 & 62.2 & 60.1 & 29.4 & 30.2 & 28.6 & ש \\
\hline 69 & 68 & 85 & 50 & 61.8 & 63.1 & 60.4 & 28.2 & 30.6 & 26.1 & 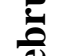 \\
\hline 70 & 78 & 88 & 68 & 61.3 & 62.5 & 60.6 & 29.7 & 35.5 & 27.3 & 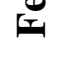 \\
\hline 71 & 77 & 85 & 69 & 62.7 & 63.5 & 61.7 & 32.3 & 37.1 & 30.3 & \\
\hline 72 & 82 & 85 & 78 & 64.4 & 65.9 & 63.4 & 36.8 & 44.0 & 32.4 & \\
\hline 73 & 70 & 85 & 54 & 66.7 & 67.6 & 65.7 & 39.1 & 41.0 & 37.4 & \\
\hline 74 & 58 & 84 & 32 & 67.7 & 68.4 & 67.3 & 37.6 & 41.3 & 34.1 & \\
\hline 75 & 58 & 75 & 40 & 67.3 & 68.3 & 65.7 & 38.0 & 40.2 & 36.4 & \\
\hline 76 & 69 & 89 & 49 & 68.0 & 68.9 & 66.6 & 41.9 & 45.7 & 39.6 & \\
\hline 77 & 80 & 89 & 70 & 68.4 & 69.2 & 67.1 & 43.2 & 45.6 & 40.3 & \\
\hline 78 & 65 & 85 & 44 & 66.6 & 79.1 & 56.3 & 37.4 & 40.1 & 35.9 & \\
\hline 79 & 71 & 85 & 57 & 63.6 & 65.2 & 61.0 & 35.8 & 37.6 & 32.4 & \\
\hline 80 & 80 & 85 & 74 & 65.8 & 66.2 & 64.7 & 33.5 & 34.8 & 32.0 & \\
\hline 81 & 77 & 85 & 69 & 66.0 & 66.6 & 65.2 & 34.4 & 35.9 & 33.7 & \\
\hline 82 & 75 & 85 & 64 & 66.4 & 67.3 & 64.7 & 36.4 & 37.5 & 35.3 & \\
\hline 83 & 73 & 82 & 64 & 65.7 & 68.0 & 63.0 & 37.2 & 37.6 & 36.6 & \\
\hline 84 & 73 & 82 & 64 & 63.5 & 70.4 & 58.7 & 35.7 & 36.8 & 34.9 & \\
\hline 85 & 72 & 85 & 59 & 63.8 & 64.5 & 61.5 & 36.1 & 37.0 & 34.6 & $\stackrel{\theta}{\theta}$ \\
\hline 86 & 57 & 81 & 32 & 63.8 & 79.0 & 52.4 & 33.6 & 37.0 & 27.0 & \\
\hline 87 & 60 & 84 & 36 & 59.9 & 76.3 & 50.2 & 34.7 & 36.5 & 33.2 & ల \\
\hline 88 & 56 & 84 & 28 & 57.5 & 73.6 & 49.2 & 34.5 & 35.5 & 33.7 & $\stackrel{\pi}{\pi}$ \\
\hline 89 & 49 & 75 & 22 & 56.5 & 72.0 & 47.9 & 34.4 & 36.0 & 32.8 & \\
\hline 90 & 55 & 81 & 28 & 55.050 & 56.990 & 52.870 & 35.696 & 35.860 & 34.290 & \\
\hline
\end{tabular}

John H. Digitalysigned by John H. Hagen

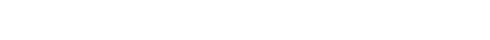

Hagen 